\title{
Current Research Trends and the Need for Localization in Ultrapure Water Production Facilities in Semiconductor Industries
}

\author{
Boungsu Kwon $^{1 \odot} \cdot$ Sangho Lee $^{2 \oplus} \cdot$ Seoktae Kang $^{3 \oplus} \cdot$ Jaelim Lim $^{1,+\oplus}$ \\ ${ }^{1} \mathrm{~K}$-water Research Institute \\ ${ }^{2}$ Department of Civil and Environmental Engineering, Kookmin University \\ ${ }^{3}$ Department of Civil and Environmental Engineering, Korea Advanced Institute of Science and Technology
}

(Received September 1, 2020; Revised September 16, 2020; Accepted September 28, 2020)

Objectives: This study aims to summarize the market status, patent applications, and technology trends for the production of ultrapure water in semiconductor industries. In addition, the potential of technological localization of ultrapure water production facility is reviewed in order to incubate domestic core technologies as well as to reduce the technical dependence to the market stake holders.

Methods: Through the collection and summary of information from global water institute (GWI), market analyst firms in ultrapure water fields, and the patent analysis for the past 10 years, the technological gap between domestic and market leading in Japan, the United States, and Europe were analyzed. In addition, the research trend related to the core removal processes for the production of ultrapure water was also analyzed.

Results and Discussion: As a result of market analysis in the industrial water sector, the capital investment is expected to reach USD 39.9 billion by 2024, with a steady growth of $4.1 \%$ per year. The unit processes required for the production of ultrapure water becomes more complex and diversified, and the recent technological advancement has been mainly put on the development of eco-friendly water treatment processes such as electrodeionization (EDI) in order to reduce the chemical usage. In addition, research on the development of new processes for the treatment of hardly degradable trace substances (i.e. urea, THM, IPA, etc.) is actively under investigation. However, the patent analysis revealed that the three Japanese companies occupied $71 \%$ of the world's patents on the ultrapure water production.

Conclusions: In ultrapure water production technology, the design of unit processes is important, and the design of a system that combines and arranges unit processes is the core technology. Thus, the incubation of domestic companies that have ability to design the array of unit processes for ultrapure water production is necessary for the localization of ultrapure water technology. However, although a few companies have completed the commercialization of core technologies, there is lack of the test field to evaluate the long-term performance of products. Therefore, for the development of domestic technologies in the ultrapure water production, it is necessary to construct a test-bed capable of evaluating the performance of domestic products. In addition, it is expected that localization of ultrapure water production technology will be facilitated with the participation of consumers.

Keywords: Ultrapure Water, Market Analysis, Research Trend, Design Technology, Patent Analysis

The Korean text of this paper can be translated into multiple languages on the website of http:/jksee.or.kr through Google Translator. 


\title{
반도체 제조용 초순수 생산기술 동향 및 국산화 필요성
}

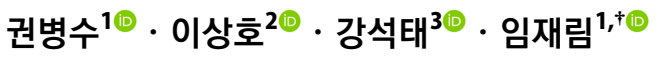 \\ 'K-water연구원 \\ 2국민대학교 건설시스템공학부 \\ 3한국과학기술원 건설 및 환경공학과
}

목적: 본 연구에서는 대외 의존성이 높은 초순수 분야에 대한 시장현황, 특허출원 및 기술 동향을 분석하여 기술 의존성 탈피를 위한 초순수 생산기술 국산화 기술개발의 방향성을 검토하고자 한다.

방법 : 초순수 분야의 시장 및 특허분석, 특히, 기술을 선점하고 있는 일본 및 미국, 유럽의 공정기술을 보유한 기 업들을 분석하였다. 또한, 제거대상 물질별 공정기술, 핵심소재의 연구동향, 특허 출원동향 등을 세밀히 분석하였 다.

결과 및 토의: 고순도 공업용수 분야의 시장분석 결과 ' 24 년까지 자본투자는 399 억달러로 연평균 $4.1 \%$ 의 꾸준한 성장세가 예상된다. 초순수 생산을 위해 요구되는 수처리 단위공정은 점점 더 복잡하고 다양해지고 있으며 최근 단위 공정의 기술 발전은 수처리를 위한 약품을 절감하기 위해 전기탈이온(EDI)과 같은 친환경 수처리공정을 개발 하는 추세이다. 또한, 난분해성 미량 물질(i.e. Urea, THM, IPA 등)의 처리를 위한 신공정 개발에 관한 연구를 진행 중이다. 초순수 관련 특허 동향 분석 결과 일본의 소수 기업에서 전세계 특허의 $71 \%$ 를 점유하고 있다.

결론 : 초순수 생산기술에서는 공정의 설계가 중요하며 단위 공정의 설계뿐만 아니라 단위 공정을 조합하여 배치하 는 시스템의 설계가 초순수 기술의 핵심이다. 초순수 생산을 위한 단위 공정에 대한 기술을 보유한 국내 기업들은 다양하게 있으나, 현장 적용이 가능한 상용화 기술 및 운영을 통한 성능 보장 능력이 부족한 실정이다. 따라서 초 순수 분야의 국산화 기술 개발은 단위 공정의 경우 현장 적용을 위한 테스트베드의 구축이 필요하며 수요처가 함 께 기술 개발에 참여한다면 특정 국가의 소수만이 보유하고 있는 초순수 생산기술의 국산화 개발이 앞당겨질 것으 로 예상된다.

주제어 : 초순수, 시장분석, 연구동향, 설계기술, 특허분석

\section{1. 서론}

\section{1. 초순수의 정의}

국내 용수공급 시스템은 국가나 지자체가 소유한 댐이나 하천의 취수장에서 원수를 취수하여 정수장에서 적정한 처 리를 하여 수용가(가정 및 산업체)에 공급하고 있다. 이중 산 업체에서 음용 목적이 아닌 제품 생산에 사용하는 용수를 수 도법 제 3 조 10 항에 정의를 하고 있으며, 제 48 조 및 제 49 조 에서 공업용수도 사업의 범위를 규정하고 있다. ${ }^{1)}$ 법에서 정 한 공업용수도는 「산업입지 및 개발에 관한 법률」제 2 조 1 호 에 따른 국가가 지정한 산업단지나 국가 지정 산업단지가 아니라도 면적이 30 만 $\mathrm{m}^{2}$ 이상 규모의 공장에 공업용수를 공급하도록 하고 있다. 또한 산업입지 및 개발에 관한 법률 제28조에는 산업단지 개발에 필요한 시설 중 용수공급 시설
및 하-폐수처리시설의 건설비의 일부를 국가가 보조할 수 있 도록 정해놓고 있다. 따라서 산업체에서 사용하는 용수의 공 급은 전기, 도로, 철도 및 통신시설과 함께 국가의 기반시설 로 국가차원의 지원이 필요한 것으로 법으로 정하고 있다.)

과거에는 국가의 산업발전이 섬유, 기계 등 단순한 제조 업 중심으로 성장을 하였으므로 공업용수의 수질보다는 수 량을 고려한 공급 체계로 구축되어 왔다. 따라서 수도법 제 3 조 10 항에도 공업용수의 수질은 원수 또는 정수를 공업 용에 맞게 처리하여 공급하는 수도로 정의해 놓았을 뿐 구 체적인 수질항목은 설정되어 있지 않다. ${ }^{2)}$ 그러나 1980년대 이후 국내 산업 업종이 중화학, 전자, 반도체, 태양광 등으 로 다양화됨에 따라 요구되는 공업용수의 수질이 다양하고 고급화되기 시작하였다. ${ }^{3)}$ 이에 따라 산업단지 입주기업들의 경쟁력을 높이기 위해 2009년 8월에 개정된「산업집적 활성 
Table 1. Water quality for industry usage.

\begin{tabular}{|c|c|c|c|c|}
\hline Division & Water Quality & Use & Proportion (\%) & Detail use \\
\hline \multirow{3}{*}{$\begin{array}{c}\text { Semi/ } \\
\text { Electro/ } \\
\text { LCD/ } \\
\text { Solar }\end{array}$} & \multirow{2}{*}{$>18.2 \mathrm{M} \Omega \cdot \mathrm{cm}$} & Cleaning & 66 & Wafer manufacture, Implant, Cleaning of developing \\
\hline & & Dilution & 27 & Developing, Implant dilution \\
\hline & $>17.5 \mathrm{M} \Omega \cdot \mathrm{cm}$ & Module & 7 & Bonding, Packing, Marking \\
\hline \multirow{4}{*}{$\begin{array}{c}\text { Petro/ } \\
\text { Power Plant }\end{array}$} & $>0.1 \mathrm{M} \Omega \cdot \mathrm{cm}$ & Cooling & 55 & Cooling water of cooling tower \\
\hline & $>1.0 \mathrm{M} \Omega \cdot \mathrm{cm}$ & Process & 24 & Process water \\
\hline & $>1.0 \sim 5.0 \mathrm{M} \Omega \cdot \mathrm{cm}$ & Boiler & 21 & $\begin{array}{c}0.1 \sim 10 \mathrm{~kg} / \mathrm{cm}^{2} \text { (middle Pressure), } \\
10 \mathrm{~kg} / \mathrm{cm}^{2} \uparrow \text { (high Pressure) }\end{array}$ \\
\hline & $>18.0 \mathrm{M} \Omega \cdot \mathrm{cm}$ & Pure Chemical & - & Pure Chemical Manufacture of Semiconductor \& LCD \\
\hline \multirow{2}{*}{$\begin{array}{c}\text { Ion/ } \\
\text { Power Plant }\end{array}$} & $>0.02 \mathrm{M} \Omega \cdot \mathrm{cm}$ & Cooling & 80 & Cooling \\
\hline & $>0.1 \mathrm{M} \Omega \cdot \mathrm{cm}$ & Cleaning & 20 & Cleaning \\
\hline
\end{tabular}

Table 2. Boiler feed water quality standards (KS B 6209). ${ }^{8)}$

\begin{tabular}{|c|c|c|c|c|c|}
\hline & \multirow{2}{*}{ Division } & \multirow{2}{*}{ Cooling water quality } & \multirow{2}{*}{ Feed Water quality } & \multicolumn{2}{|c|}{ Influence } \\
\hline & & & & Corrosion & Scale \\
\hline \multirow{6}{*}{ Standards item } & $\mathrm{pH}$ at $25^{\circ} \mathrm{C}$ & $6.5 \sim 8.0$ & $6.0 \sim 8.0$ & O & 0 \\
\hline & Conductivity at $25^{\circ} \mathrm{C}(\mu \mathrm{S} / \mathrm{cm})$ & $800<$ & $200<$ & $\mathrm{O}$ & $\mathrm{O}$ \\
\hline & $\mathrm{Cl}^{-}\left(\mathrm{mg} \mathrm{Cl}^{-} / \ell\right)$ & $200<$ & $50<$ & O & \\
\hline & $\mathrm{SO}_{4}{ }^{2-}\left(\mathrm{mg} \mathrm{SO}_{4}{ }^{2-} / \ell\right)$ & $200<$ & $50<$ & O & \\
\hline & Alkalinity at $\mathrm{pH} 4.8\left(\mathrm{mg} \mathrm{CaCO}_{3} / \ell\right)$ & $100<$ & $50<$ & & O \\
\hline & Calcium hardness $\left(\mathrm{mg} \mathrm{CaCO}_{3} / \ell\right)$ & $150<$ & $50<$ & & O \\
\hline \multirow{5}{*}{ Reference item } & Turbidity (NTU) & $20<$ & $5.0<$ & O & O \\
\hline & $\mathrm{Fe}(\mathrm{mg} \mathrm{Fe} / \mathrm{l})$ & $1.0<$ & $0.3<$ & O & O \\
\hline & $\mathrm{NH}_{4}^{+}\left(\mathrm{mg} \mathrm{NH}_{4}^{+} / \ell\right)$ & $1.0<$ & $0.2<$ & O & \\
\hline & $\mathrm{SiO}_{2}(\mathrm{mg} \mathrm{SiO} / / \ell)$ & $50<$ & $10<$ & & O \\
\hline & Saturation Index (-) & $0.0 \sim 1.0$ & - & 0 & O \\
\hline
\end{tabular}

화 및 공장설립에 관한 법률 ${ }^{4)}$ 제 5 조에는 공장의 용수공급 은 국가차원의 지원이 필요한 기반시설로 정해 놓고 있다.

이렇게 국가 차원에서 공급하는 공업용수는 수질에 대한 특정한 규정이 없이, 단지 공급하는 국가(한국수자원공사) 나 지자체별 관리기준만 설정하여 운영을 하고 있다. 한국 수자원공사의 경우 내부 기준으로 공업용 침전수 수질관리 기준을 수소이온농도 $(\mathrm{pH})$ 는 5.8 8.5, 탁도는 $5 \mathrm{NTU}$ 이하로 설정하여 운영 중에 있으며 공업용수 생산을 위해 원수를 응집, 침전 처리하고 있다. ${ }^{5)}$

한국 수출액의 $40 \%$ 이상을 차지하고 있는 반도체, $\mathrm{LCD}$, 석유화학, 철강 등 주요 산업에서는 ${ }^{6}$ 정수장에서 공업용수 를 공급받아 추가로 처리하여 용수를 생산하여 Table 1과 같이 다양한 용도로 사용하고 있다.

따라서 공업용수의 수질기준이 엄격해지고 업종에 따라 다양화해짐으로써 국가 차원의 공업용수 수질기준의 재설 정이 필요하며, 첨단산업에서 사용되는 고순도의 공업용수 에 대한 국가차원의 검토가 절실하다.

현재 정수장의 공업용수를 사용하여 추가 처리하여 난방, 보일러, 냉각수의 목적으로 사용하는 경우 Table 2와 같이
KS B $6209^{8)}$ 규격으로 수질을 표준화하였다. 앞서 언급한 바와 같이 공업용수는 국가(한국수자원공사)나 지자체에서 공급하는 침전수로 정의할 수 있으며, 고순도 공업용수는 그 침전수를 각자의 목적에 맞게 처리하여 산업용으로 생산 한 물로 정의할 수 있다.

그러나 반도체 등과 같이 첨단산업에 요구되는 초고순도 의 공업용수 수질은 그간 제품의 성능이나 생산량을 파악할 수 있는 간접 지표로서 기업 내부에서 다음 Table3과 같이 공급수질의 기준을 자체적으로 설정하여 운영 중에 있다. $\left.{ }^{9}\right)$ 미국의 경우 ASTM (American Society for Testing and Materials International, 미국 재료시험 협회) 및 ASME (American Society of Mechanical Engineer, 미국 기계학회) 등에서는 산 업체의 용도별로 수질을 정의하고 있다. ASME에서는 발전/ 화학 ${ }^{10)}$ 을 ASTM D5127 $7^{11)}$ 에서는 반도체용 고순도 공업용수의 수질을 다음 Table 4와 같이 정하고 있으며, 이를 위한 수처리 공정의 성능 기준 및 평가절차를 정하여 운영 중에 있다. 따라 서 반도체 산업이 주력 수출 사업인 한국도 반도체에 사용되 는 공업용수의 수질 기준을 국가차원에서 설정하고 관리할 필요가 있다. 
Table 3. Ultrapure water quality standards applied to semiconductor and liquid crystal display. ${ }^{9)}$

\begin{tabular}{|c|c|c|c|c|c|c|}
\hline \multirow{2}{*}{ Division } & \multicolumn{2}{|c|}{ S Semiconductor } & \multicolumn{2}{|c|}{ K Semiconductor } & \multirow{2}{*}{$\frac{\text { P Semiconductor }}{\text { E site }}$} & \multirow{2}{*}{$\frac{\text { L LCD }}{\text { F site }}$} \\
\hline & A site & B site & C site & D site & & \\
\hline Resistivity & $\geq 18.2 \mathrm{M} \Omega \cdot \mathrm{cm}$ & $\geq 18.2 \mathrm{M} \Omega \cdot \mathrm{cm}$ & $\geq 18.2 \mathrm{M} \Omega \cdot \mathrm{cm}$ & $\geq 18.2 \mathrm{M} \Omega \cdot \mathrm{cm}$ & $\geq 18.2 \mathrm{M} \Omega \cdot \mathrm{cm}$ & $\geq 18.0 \mathrm{M} \Omega \cdot \mathrm{cm}$ \\
\hline Particle (ea/ml, 0.05 um) & $\begin{array}{l}\leq 2 \text { (PVDF) } \\
\leq 5 \text { (CPVC) }\end{array}$ & $\begin{array}{l}\leq 2 \text { (PVDF) } \\
\leq 5 \text { (CPVC) }\end{array}$ & $\leq 1$ (PVDF) & $\leq 1$ (PVDF) & $\leq 1$ (PVDF) & $\begin{array}{c}\leq 10 \text { (PVDF) } \\
{[0.1 \mu \mathrm{m}]}\end{array}$ \\
\hline Bacteria (CFU/100 ml) & $\leq 0.1$ & $\leq 0.1$ & $\leq 0.1$ & $\leq 1$ & $\leq 1$ & $\leq 10$ \\
\hline TOC & $\leq 0.5 \mu \mathrm{g} / \mathrm{L}$ & $\leq 1.0 \mu \mathrm{g} / \mathrm{L}$ & $\leq 1 . \mu \mathrm{g} / \mathrm{L}$ & $\leq .5 \mu \mathrm{g} / \mathrm{L}$ & $\leq 1.0 \mu \mathrm{g} / \mathrm{L}$ & $\leq 30.0 \mu \mathrm{g} / \mathrm{L}$ \\
\hline $\mathrm{SiO}_{2}$ & $\leq 0.1 \mu \mathrm{g} / \mathrm{L}$ & $\leq 0.1 \mu \mathrm{g} / \mathrm{L}$ & $<0.1 \mu \mathrm{g} / \mathrm{L}$ & $\leq 0.1 \mu \mathrm{g} / \mathrm{L}$ & $\leq 0.1 \mu \mathrm{g} / \mathrm{L}$ & $\leq 1 \mu \mathrm{g} / \mathrm{L}$ \\
\hline DO & $\leq 3.0 \mu \mathrm{g} / \mathrm{L}$ & $\leq 3.0 \mu \mathrm{g} / \mathrm{L}$ & $\leq 1.0 \mu \mathrm{g} / \mathrm{L}$ & $\leq 1.0 \mu \mathrm{g} / \mathrm{L}$ & $\leq 1.0 \mu \mathrm{g} / \mathrm{L}$ & $\leq 20.0 \mu \mathrm{g} / \mathrm{L}$ \\
\hline $\mathrm{Ca}$ & $\leq 10 \mathrm{ppt}$ & $\leq 10 \mathrm{ng} / \mathrm{L}$ & $<2 \mathrm{ng} / \mathrm{L}$ & - & - & - \\
\hline $\mathrm{Na}$ & $\leq 10 \mathrm{ng} / \mathrm{L}$ & $\leq 10 \mathrm{ng} / \mathrm{L}$ & $<2.5 \mathrm{ng} / \mathrm{L}$ & $\leq 0.002 \mu \mathrm{g} / \mathrm{L}$ & $\leq 0.005 \mu \mathrm{g} / \mathrm{L}$ & $\leq 0.5 \mu \mathrm{g} / \mathrm{L}$ \\
\hline $\mathrm{Cu}$ & $\leq 10 \mathrm{ng} / \mathrm{L}$ & $\leq 10 \mathrm{ng} / \mathrm{L}$ & $<1 \mathrm{ng} / \mathrm{L}$ & $\leq 0.005 \mu \mathrm{g} / \mathrm{L}$ & $\leq 0.005 \mu \mathrm{g} / \mathrm{L}$ & $\leq 0.5 \mu \mathrm{g} / \mathrm{L}$ \\
\hline K & $\leq 10 \mathrm{ng} / \mathrm{L}$ & $\leq 10 \mathrm{ng} / \mathrm{L}$ & $<2.5 \mathrm{ng} / \mathrm{L}$ & $\leq 0.005 \mu \mathrm{g} / \mathrm{L}$ & $\leq 0.005 \mu \mathrm{g} / \mathrm{L}$ & $\leq 0.5 \mu \mathrm{g} / \mathrm{L}$ \\
\hline $\mathrm{Zn}$ & $\leq 10 \mathrm{ng} / \mathrm{L}$ & $\leq 10 \mathrm{ng} / \mathrm{L}$ & $<1 \mathrm{ng} / \mathrm{L}$ & $\leq 0.005 \mu \mathrm{g} / \mathrm{L}$ & $\leq 0.005 \mu \mathrm{g} / \mathrm{L}$ & $\leq 0.5 \mu \mathrm{g} / \mathrm{L}$ \\
\hline $\mathrm{Fe}$ & $\leq 10 \mathrm{ng} / \mathrm{L}$ & $\leq 10 \mathrm{ng} / \mathrm{L}$ & $<1 \mathrm{ng} / \mathrm{L}$ & - & $\leq 0.005 \mu \mathrm{g} / \mathrm{L}$ & $\leq 0.5 \mu \mathrm{g} / \mathrm{L}$ \\
\hline $\mathrm{Cl}$ & $\leq 50 \mathrm{ng} / \mathrm{L}$ & $\leq 50 \mathrm{ng} / \mathrm{L}$ & $<5 \mathrm{ng} / \mathrm{L}$ & $\leq 0.005 \mu \mathrm{g} / \mathrm{L}$ & $\leq 0.005 \mu \mathrm{g} / \mathrm{L}$ & $\leq 0.5 \mu \mathrm{g} / \mathrm{L}$ \\
\hline $\mathrm{Li}$ & $\leq 10 \mathrm{ng} / \mathrm{L}$ & $\leq 10 \mathrm{ng} / \mathrm{L}$ & $<5 \mathrm{ng} / \mathrm{L}$ & $\leq 0.005 \mu \mathrm{g} / \mathrm{L}$ & - & - \\
\hline $\mathrm{NH}_{4}$ & $\leq 50 \mathrm{ng} / \mathrm{L}$ & $\leq 50 \mathrm{ng} / \mathrm{L}$ & $<5 \mathrm{ng} / \mathrm{L}$ & $\leq 0.005 \mu \mathrm{g} / \mathrm{L}$ & - & - \\
\hline $\mathrm{NO}_{2}$ & $\leq 50 \mathrm{ng} / \mathrm{L}$ & $\leq 50 \mathrm{ng} / \mathrm{L}$ & $<5 \mathrm{ng} / \mathrm{L}$ & $\leq 0.005 \mu \mathrm{g} / \mathrm{L}$ & - & - \\
\hline $\mathrm{PO}_{4}$ & $\leq 50 \mathrm{ng} / \mathrm{L}$ & $\leq 50 \mathrm{ng} / \mathrm{L}$ & $<5 \mathrm{ng} / \mathrm{L}$ & $\leq 0.005 \mu \mathrm{g} / \mathrm{L}$ & - & - \\
\hline $\mathrm{SO}_{4}$ & $\leq 50 \mathrm{ng} / \mathrm{L}$ & $\leq 50 \mathrm{ng} / \mathrm{L}$ & $<0.1 \mu \mathrm{g} / \mathrm{L}$ & - & $\leq 0.02 \mu \mathrm{g} / \mathrm{L}$ & - \\
\hline Residue & $\leq 1 \mu \mathrm{g} / \mathrm{L}$ & $\leq 1 \mu \mathrm{g} / \mathrm{L}$ & & $\leq 0.5 \mu \mathrm{g} / \mathrm{L}$ & $\leq 1 \mu \mathrm{g} / \mathrm{L}$ & - \\
\hline Temperature $\left({ }^{\circ} \mathrm{C}\right)$ & $25 \pm 1$ & $25 \pm 1$ & $24 \pm 1.05$ & $25 \pm 1$ & $25 \pm 1$ & $25 \pm 2$ \\
\hline Pressure $\left(\mathrm{kg} / \mathrm{cm}^{2}\right)$ & $\geq 1.5$ & $\geq 1.5$ & $\geq 1.5$ & $\geq 1.5$ & $\geq 1.5$ & $1.5 \sim 3.0$ \\
\hline
\end{tabular}

Table 4. Ultrapure water quality standards applied to semiconductor and electronics, ASTM D5127-13. ${ }^{11)}$

\begin{tabular}{|c|c|c|c|c|c|c|c|}
\hline Division & $\begin{array}{l}\text { Type } \\
\text { E-1 }\end{array}$ & $\begin{array}{l}\text { Type } \\
\text { E-1.1 }\end{array}$ & $\begin{array}{l}\text { Type } \\
\text { E-1.2 }\end{array}$ & $\begin{array}{l}\text { Type } \\
\text { E-1.3 }\end{array}$ & $\begin{array}{l}\text { Type } \\
\text { E-2 }\end{array}$ & $\begin{array}{l}\text { Type } \\
\text { E-3 }\end{array}$ & $\begin{array}{l}\text { Type } \\
\text { E-4 }\end{array}$ \\
\hline Linewidth (microns) & $1.0-0.5$ & $0.35-0.25$ & $0.18-0.09$ & $0.06-0.03$ & $5.0-1.0$ & $>5.0$ & - \\
\hline Resistivity, $25^{\circ} \mathrm{C}$ (on-line) & 18.1 & 18.2 & 18.2 & 18.2 & 16.5 & 12 & 0.5 \\
\hline $\mathrm{TOC}(\mu \mathrm{g} / \mathrm{L})(<10 \mu \mathrm{g} / \mathrm{L})$ & 5 & 2 & 1 & 1 & 50 & 300 & 1,000 \\
\hline On-line dissolved oxygen $(\mu \mathrm{g} / \mathrm{L})$ & 25 & 10 & 3 & 10 & - & - & - \\
\hline On-line residue evaporation ( $\mu \mathrm{g} / \mathrm{L})$ & 1 & 0.5 & 0.1 & - & - & - & - \\
\hline On-line particles/L (>0.05 um) & $\begin{array}{c}1,000 \\
(0.1-0.2 \mu \mathrm{m})\end{array}$ & $\begin{array}{c}1,000 \\
(0.05-0.1 \mu \mathrm{m})\end{array}$ & $\begin{array}{c}200 \\
(0.05-0.1 \mu \mathrm{m})\end{array}$ & $\begin{array}{c}500 \\
(>0.05 \mu \mathrm{m})\end{array}$ & - & - & - \\
\hline SEM particles/L (0.1-0.2 um) & 1000 & 350 & $<100$ & N/A & $\begin{array}{c}3,000 \\
(0.2-0.5 \mu \mathrm{m})\end{array}$ & $\begin{array}{c}10,000 \\
(0.5-1 \mu \mathrm{m})\end{array}$ & $\begin{array}{l}100,000 \\
(10 \mu \mathrm{m})\end{array}$ \\
\hline Bacteria in CFU/volume (100 mL) & 5 & 3 & 1 & N/A & 10 & 50 & 100 \\
\hline Silica-total $(\mu \mathrm{g} / \mathrm{L})$ & 5 & 3 & 1 & 0.5 & 10 & 50 & 1,000 \\
\hline Silica-dissolved ( $\mu \mathrm{g} / \mathrm{L})$ & 3 & 1 & 0.5 & 0.5 & - & - & - \\
\hline Anions and ammonium by IC ( $\mu \mathrm{g} / \mathrm{L})$ & 0.1 & $0.05-0.1$ & $0.02-0.05$ & 0.05 & 1 & 5 & 500 \\
\hline Metals by ICP/MS ( $\mu \mathrm{g} / \mathrm{L})$ & $0.05-0.3$ & $0.02-0.1$ & $0.005-0.05$ & $0.001-0.1$ & 1 & 5 & 500 \\
\hline Temperature stability (K) & & & & \pm 1 & - & - & - \\
\hline Dissolved nitrogen on-line (mg/L) & & & & 8-18 & - & - & - \\
\hline \multicolumn{8}{|c|}{ 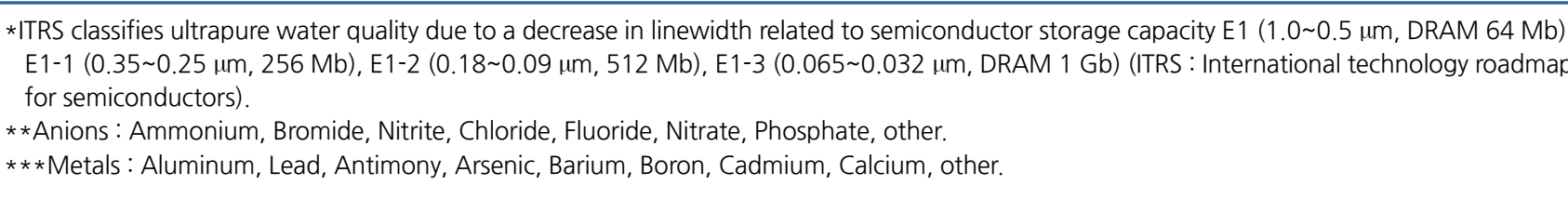 } \\
\hline
\end{tabular}


Table 5. Water costs according to type of water. ${ }^{13)}$

\begin{tabular}{|c|c|c|}
\hline Division & Type of water & Water cost $\left(W / m^{3}\right)$ \\
\hline The raw water of dams & The raw water of dams & 52.7 \\
\hline \multirow{4}{*}{ Wide area water supply } & -(average) & 323.6 \\
\hline & The raw water & 233.7 \\
\hline & Water purification treatment & 432.8 \\
\hline & Industrial water & 328.0 \\
\hline
\end{tabular}

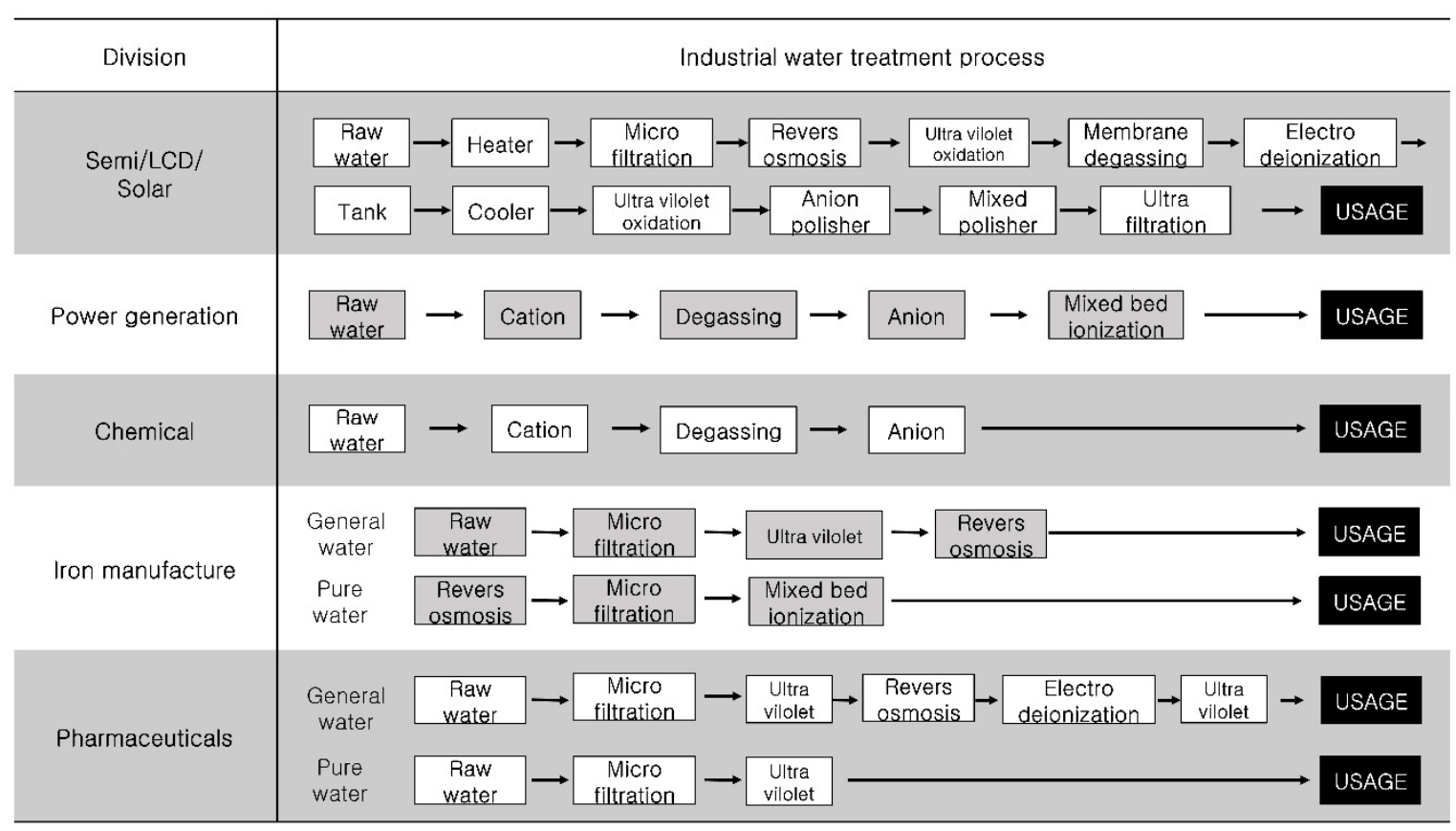

Fig. 1. Flow chart of water treatment process classified by industry.

일반적으로 정수장 공업용수보다 더 정화 처리된 공업용 수를 순수 또는 초순수로 통용하여 사용 중에 있으며 흔히 반도체와 같은 전자산업에서 사용되는 공업용수를 초순수 로 통칭하고 있을 뿐 순수와 초순수의 명확한 수질기준은 설정되어 있지 않다. 다만 반도체 산업용 공업용수를 생산 하는 용수 설계 기술을 독점하고 있는 일본에서 “초순수(初 純水)”라는 용어를 만들어 사용하고 있으므로 향후 미국의 표준기준인 ASTM D5127에서 설정한 반도체 산업용 공업 용수의 수질기준을 바탕으로 현장에서 사용하는 순수와 초 순수의 기준을 국가차원에서 규정할 필요가 있다.

\section{2. 초순수 연구개발의 필요성}

앞서 Table 3에 제시된 바와 같이 반도체에서 요구되는 공업용수(초순수)는 일반적인 정수장 정수에 비해 높은 순 도의 수질을 요구하고 있다. 따라서, 이러한 수질을 만족시 키기 위해 Fig.1과 같이 다양한 단위 수처리 공정을 적용하 여 용수를 생산하고 있다.

따라서 초순수 생산은 현존하는 수처리 엔지니어링 기술
의 종합 시스템이며 고난이도의 수처리 설계, 운영기술이 요구되며, 수질 분석 또한 고가의 장비와 숙련된 전문가의 분석 기술이 요구되고 있다.

또한 국내의 수돗물 요금단가는 수도법, 수자원공사법에 따라 환경부장관이 승인하며, 수돗물요금은 지역사회와 국 토의 균형발전을 위하여 전국적으로 동일 요금을 적용하고 있으며, 수처리 정도에 따라 수종을 구분하여 Table5와 같 이 요금을 적용하고 있다. 다만 한국수자원공사에서 공급하 는 순수 수준의 용수는 별도 협약에 의해 원수 금액을 포함 하여 요금은 721 원 $/ \mathrm{m}^{3}$ 으로 ${ }^{12)}$ 공급하고 있다. 그러나 초순수 는 이보다 2-3배 높은 운영단가를 받고 운영 중에 있으며, 운영의 주체 또한 외국의 전문 엔지니어링 업체가 국내에서 영업 중이다.

전세계 공업용수 중 전자산업에 사용되는 초순수는 아시 아 지역에 $62 \%$ 이상 생산되어 소비되고 있고, 이 중 반도체 산업의 선두 주자인 한국의 초순수 사용량은 세계적으로 높 은 비율을 차지할 것으로 예상된다. 따라서 세계시장에서 큰 비중을 차지하며 공업용수 중 가장 고부가가치 용수인 


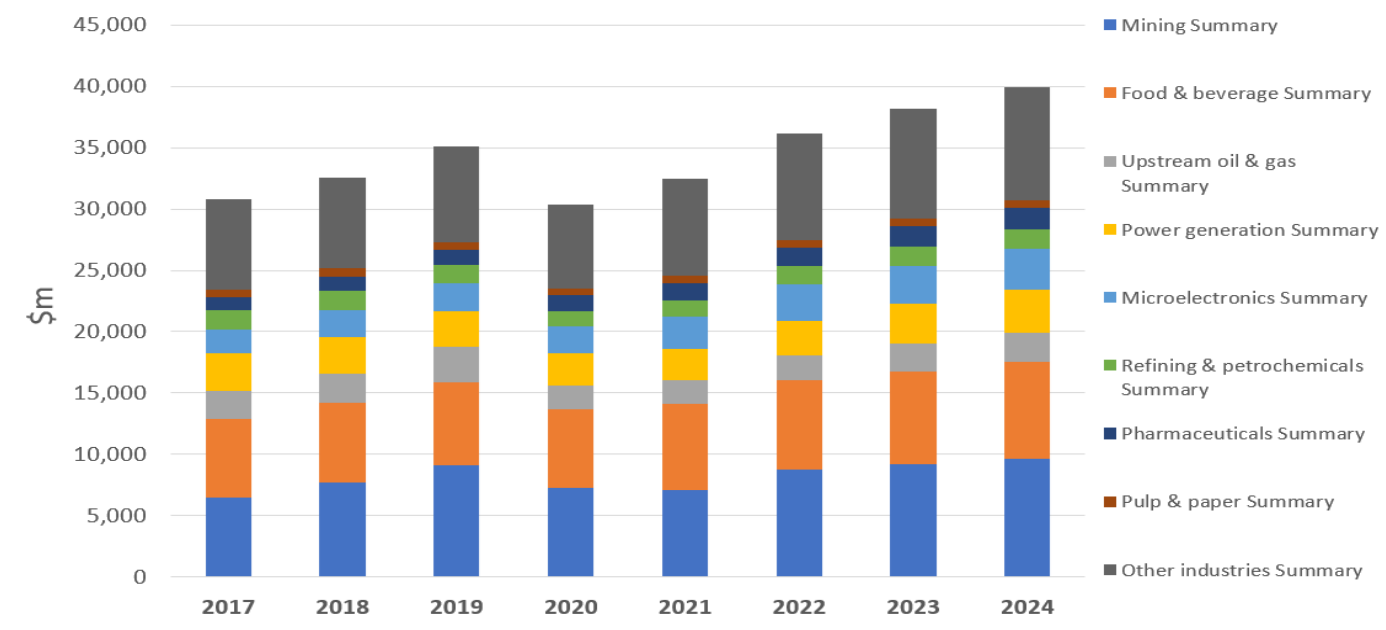

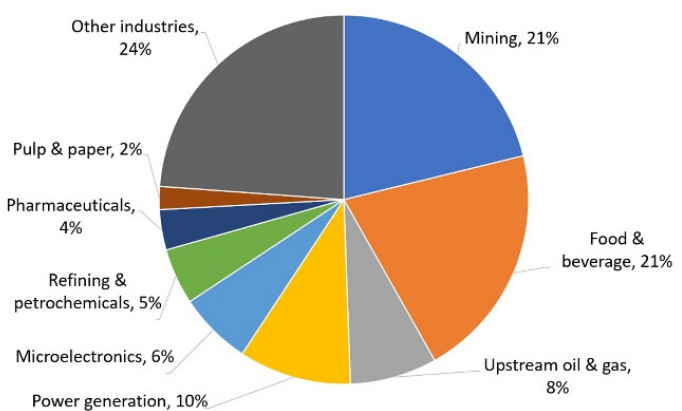

2017

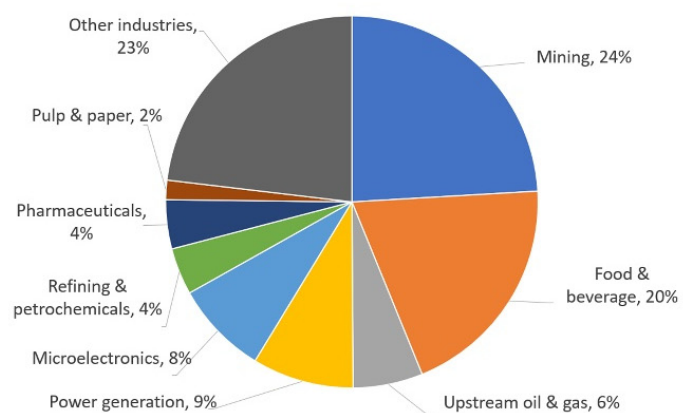

2024

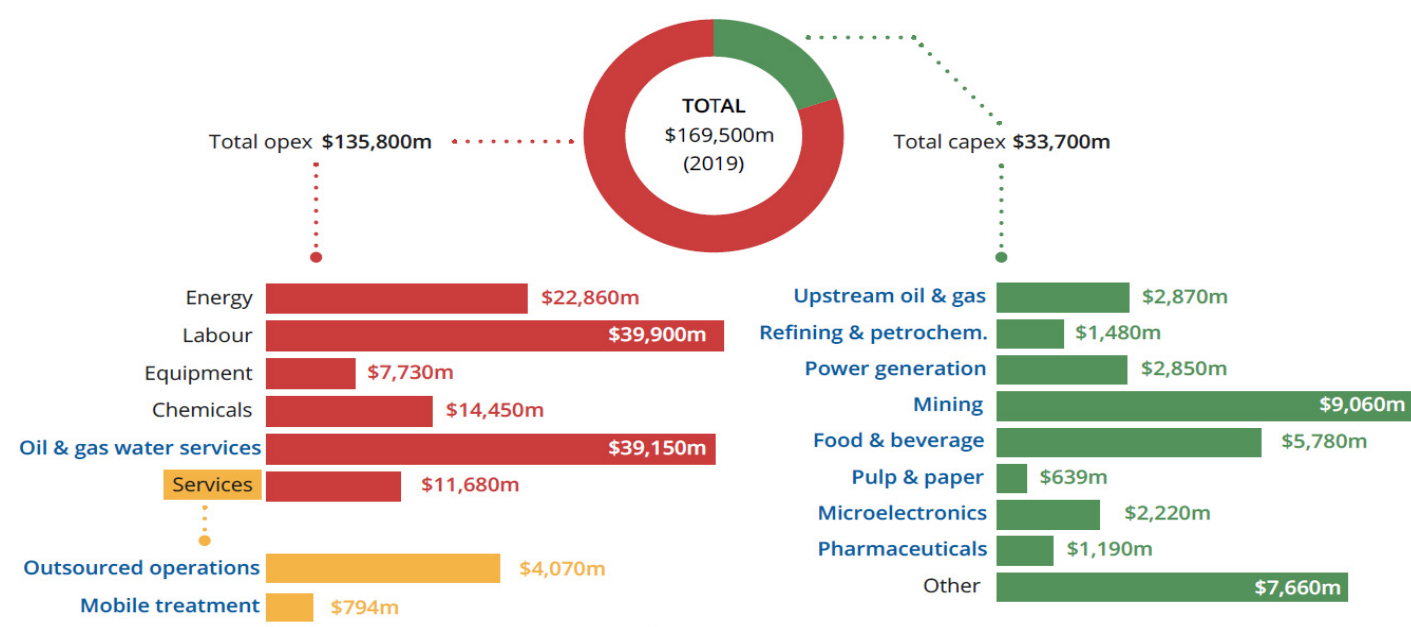

Fig. 2. Industrial water market (Global water data). ${ }^{15)}$

초순수 생산 기술은 향후 물산업 시장에서 중요한 역할을 할 것으로 예상된다. 하지만 이러한 초순수 생산 기술은 일 본의 특정 업체에서만 독점적으로 설계와 이의 보증능력을 가지고 있어 경제적 가치 이외에 국가의 공업용수 공급의
“물 안보차원”에서 중요한 기술로 인식되고 있다.

특히 최근 미·중 무역분쟁과 보호무역주의 확대 및 일본 의 한국 수출규제는 WTO 중심의 자유 무역질서에 대한 위 협 가능성이 있다. 글로벌 가치사슬(Global value chain)에 
Table 6. Global water treatment and distribute market ${ }^{15)}$ (Unit : \$m).

\begin{tabular}{|c|c|c|c|c|c|c|}
\hline \multirow{2}{*}{ Division } & \multicolumn{2}{|c|}{ Total } & \multicolumn{2}{|c|}{ Capital expenditure } & \multicolumn{2}{|c|}{ Operating expenditure } \\
\hline & 2020 & 2024 & 2020 & 2024 & 2020 & 2024 \\
\hline $\begin{array}{c}\text { Total } \\
\text { (Rate of increase) }\end{array}$ & 790,174 & $\begin{array}{l}895,474 \\
(3.33 \%)\end{array}$ & 284,562 & $\begin{array}{l}337,563 \\
(4.66 \%)\end{array}$ & 505,612 & $\begin{array}{l}557,912 \\
(3.61 \%)\end{array}$ \\
\hline Utility water & 82,846 & 96,209 & 82,846 & 96,209 & \multirow{8}{*}{371,204} & \multirow{8}{*}{417,085} \\
\hline -Water networks & & & 55,728 & 64,993 & & \\
\hline -Water plants & & & 27,118 & 31,215 & & \\
\hline Water resources & 22,273 & 27,204 & 22,273 & 27,204 & & \\
\hline Sea and brackish water & 3,126 & 4,009 & 3,126 & 4,009 & & \\
\hline Utility \& waste water & 141,226 & 170,179 & 141,226 & 170,179 & & \\
\hline -Waste water networks & & & 80,738 & 91,401 & & \\
\hline -Waste water plants & & & 60,488 & 78,778 & & \\
\hline Industrial water & 169,500 & 180,789 & 35,092 & 39,963 & 134,408 & 140,827 \\
\hline
\end{tabular}

Table 7. Capital expenditure forecast for industrial water sector ${ }^{15)}$ (Unit : \$m).

\begin{tabular}{cccccccccc} 
Capital expenditure $(\$ \mathrm{~m})$ & 2017 & 2018 & 2019 & 2020 & 2021 & 2022 & 2023 & 2024 \\
Total & 30,778 & 32,588 & 35,092 & 30,369 & 32,487 & 36,105 & 38,130 & 39,963 \\
\hline Mining & 6,520 & 7,704 & 9,090 & 7,247 & 7,074 & 8,749 & 9,180 & 9,621 \\
\hline Food \& beverage & 6,350 & 6,527 & 6,799 & 6,415 & 7,070 & 7,344 & 7,615 & 7,900 \\
\hline Upstream oil & 2,346 & 2,344 & 2,868 & 1,941 & 1,902 & 1,992 & 2,233 & 2,419 \\
\hline Power gener. & 3,028 & 2,993 & 2,934 & 2,646 & 2,506 & 2,804 & 3,257 & 3,521 \\
\hline Microelectronics & 1,973 & 2,179 & 2,223 & 2,226 & 2,653 & 2,930 & 3,089 & 3,258 \\
\hline Refining \& petro. & 1,514 & 1,608 & 1,505 & 1,227 & 1,319 & 1,492 & 1,602 & 1,626 \\
\hline Pharmaceuticals & 1,085 & 1,161 & 1,246 & 1,286 & 1,390 & 1,490 & 1,598 & 1,704 \\
\hline Pulp \& paper & 621 & 633 & 639 & 559 & 611 & 658 & 665 & 672 \\
\hline Other industries & 7,341 & 7,438 & 7,787 & 6,822 & 7,962 & 8,645 & 8,892 & 9,241 \\
\hline
\end{tabular}

따른 국제적 분업에서 나아가, 국제정세 변화에 대한 위기 관리 능력의 필요성이 대두된다. 이번 일본 정부는 반도체· 디스플레이 분야 3 개 품목(불화수소, 폴리아미드, 레지스트) 에 대해 수출규제를 '19년 7월 4일 단행하였으며, 뿐만 아 니라 한국을 백색국가에서 배제하는 것으로 '19년 8월 2일 결정하여 ' 19 년 8월 28 일 시행하였다. 일본의 반도체 소재 수출 규제 및 백색국가 제외는 수요기업의 공급처 관리를 넘어 경제 안보차원에서 근본적 문제해결을 위한 전략적 변 화가 요구된다. ${ }^{14)}$

특히 초순수 설비의 주요 기자재인 UF, 열교환기, 자동밸 브는 전략물자에 해당되어 수입기간 지연에 따른 반도체 제 조 차질이 우려된다. ${ }^{14)}$ 따라서 국내 공업용수 생산 기술은 단순한 수처리 분야의 기술력 확보를 넘어, 국가 산업계 전 반의 기술 및 생산 능력에 영향을 받는다는 점을 인식해야 할 것이다.

\section{2. 초순수 시장 및 산업 동향}

\section{1. 초순수 관련 국내외 시장 현황 및 미래 전망}

2020년도의 세계 물 시장 규모는 Table 6과 같이 총 7,797

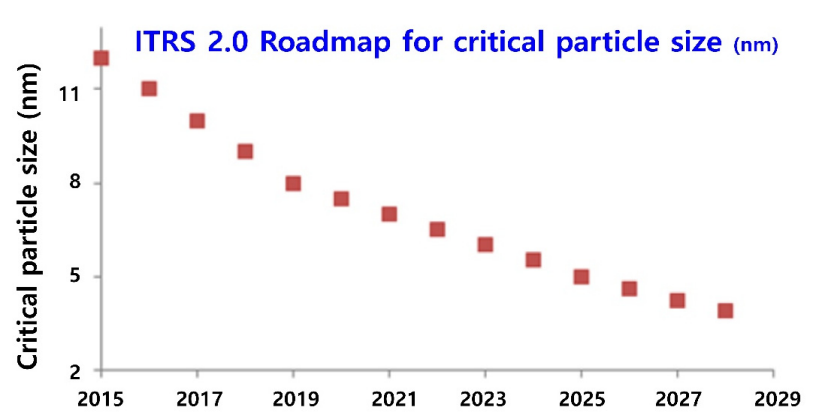

Fig. 3. IRDS roadmap for critical particle size $(\mathrm{nm})$.

억 달러이며, Global water data에서는 산업분야를 오일 및 가스, 석유정제, 발전, 광업, 식품/음료, 펄프제지, 전자, 약 품 분야로 구분하고 있으며 침전수를 공급받아 각 산업분야 별 사용하는 고순도 공업용수는 총 1,544 억 달러 규모로 추 정된다(Global water data). ${ }^{15)}$

이를 자금 투입의 성격에 따라 자본적 지출인 자본투자부 문(capital expenditure)과 수익적 지출인 운영부문(operating expenditure)으로 각각 구분하면, 2020년도의 자본투자비용 은 총 2,759억 달러이며, 고순도 공업용수 설비투자에 303 억 달러가 투자될 것으로 전망된다. 또한 운영 부문에 있어 
Table 8. Capital expenditure forecast for domestic industrial water (Unit : \$m). ${ }^{17)}$

\begin{tabular}{ccccccccc} 
Capital expenditure & 2013 & 2014 & 2015 & 2016 & 2017 & 2018 & 2019 & 2020 \\
Utility water & $1,715.0$ & $1,688.6$ & $1,674.7$ & $1,671.1$ & $1,654.5$ & $1,667.2$ & $1,683.0$ & $1,698.9$ \\
\hline Water networks & 565.4 & 563.9 & 560.2 & 554.6 & 549.2 & 553.3 & 558.1 & 563.0 \\
\hline Water treatment plants & 507.8 & 507.9 & 506.1 & 502.5 & 498.8 & 503.7 & 508.1 & 512.6 \\
\hline Water resources (excl. desalination) & 604.2 & 603.5 & 600.5 & 595.4 & 590.2 & 595.4 & 600.6 & 605.9 \\
\hline Seawater\& brackish water desal. & 37.5 & 13.3 & 7.8 & 18.7 & 16.4 & 14.8 & 16.1 & 17.4 \\
\hline Utility wastewater capital expenditure & $3,540.6$ & $3,753.1$ & $3,978.3$ & $4,217.0$ & $4,343.5$ & $4,473.5$ & $4,384.3$ & $4,296.6$ \\
\hline Wastewater networks & $1,999.8$ & $2,079.9$ & $2,162.2$ & $2,246.5$ & $2,307.8$ & $2,370.4$ & $2,323.0$ & $2,276.5$ \\
\hline Wastewater treatment plants & $1,173.6$ & $1,283.5$ & $1,372.0$ & $1,471.4$ & $1,502.8$ & $1,534.4$ & $1,503.7$ & $1,473.7$ \\
\hline Sludge management & 367.2 & 390.7 & 444.1 & 499.1 & 532.9 & 569.0 & 557.6 & 546.4 \\
\hline Industrial capital expenditure & 525.8 & 549.1 & 585.1 & 597.0 & 638.2 & 686.2 & 726.3 & 769.0 \\
\hline Total capital expenditure & $5,781.4$ & $5,990.8$ & $6,238.0$ & $6,485.1$ & $6,636.2$ & $6,827.9$ & $6,793.6$ & $6,764.4$ \\
\hline Total operating expenditure & $5,435.9$ & $5,690.9$ & $5,866.9$ & $6,054.2$ & $6,267.8$ & $6,431.1$ & $6,681.4$ & $6,935.3$ \\
\hline Total expenditure & $11,217.3$ & $11,681.7$ & $12,104.9$ & $12,539.3$ & $12,904.0$ & $13,259.0$ & $13,475.0$ & $13,699.7$ \\
\hline
\end{tabular}

Table 9. Industrial water consumption ratio by use. ${ }^{19)}$

\begin{tabular}{|c|c|c|c|c|c|c|c|}
\hline & \multirow{2}{*}{ Division } & \multirow{2}{*}{ Use } & \multicolumn{5}{|c|}{ Industrial sector } \\
\hline & & & Semiconductor & LCD & Solar panel & Microelectronics & Other \\
\hline \multirow{3}{*}{ Ratio } & Ultrapure water & Production process & $40 \%$ & $40 \%$ & $29 \%$ & $5 \%$ & - \\
\hline & Pure water & Boiler feed water & $10 \%$ & $10 \%$ & $10 \%$ & $10 \%$ & $10 \%$ \\
\hline & Industrial water & Cooling water & $50 \%$ & $50 \%$ & $61 \%$ & $86 \%$ & $90 \%$ \\
\hline
\end{tabular}

서는 전체 5,056 억 달러의 비용이 소요될 것으로 예측되며 고순도 공업용수 운영에 1,240 억 달러가 필요할 것이다.

고순도 공업용수에 대한 자본투자는 Table 7 및 Fig. 2와 같이 원유 개발 및 천연자원 가격인상에 따른 광업의 수익 성 향상에 따라 동 분야에 대한 물 관련 자본투자는 2024년 까지 연평균 $6.7 \%$ 의 꾸준한 성장세가 예상된다. 코로나 19 발생에 따른 제약산업의 투자에 따른 고순도 공업용수 분 야의 자본투자도 $6.7 \%$ 로 증가 예상되며, 비대면 방식의 소 통으로 인해 반도체 등의 산업의 투자가 $7.6 \%$ 로 대폭 증가 할 것으로 예상된다. 이와 더불어 한층 강화되는 산업폐수 규제정책 역시 시장에서 새로운 수요를 창출할 것으로 전 망된다. 예를 들어 발전소 방류수 중 탈황 장치를 추가로 요구하거나, 생활하수처리장으로 유입될 수 있는 화학물질 추적 검사에 필요한 장치 등이 추가적으로 필요할 것으로 전망된다.

반도체 제조관련 로드맵을 제공하는 International Roadmap for Devices and Systems (IRDS)에서는 제품의 불량을 방지하 기 위하여 물에 포함된 미세입자를 탐지하고 제거하기 위한 노력을 진행 중이다. Fig. 3과 같이 반도체 제조공정은 $10 \mathrm{~nm}$ 이하로 미세공정이 진행 중이며 $10 \mathrm{~nm}$ 의 작은 미세입자의 모니터링 및 입자를 제거할 수 있는 여과 기술에 대한 수요 증가로 이 분야에 대한 기회가 확대되고 있다.

글로벌 초순수 시장 현황에 대해 전문분석 기관의 자료에 따르면 2025년 말까지 61억 2,000만 달러로 연평균성장율
(CAGR) $7.1 \%$ 로 성장 예상되며, 초순수 시장은 몇몇 대표 플레이어들이 세계 시장을 점유하고 기술장벽이 높은 분야 이며, 초순수 시장은 반도체 웨이퍼 크기 증가에 따라 좌우 되며, 반도체 분야가 약 $50 \%$ 차지한다. ${ }^{16)}$

GWI (Global Water Intelligence, 2018)의 분석에 의하면 국내 물 시장은 Table 8과 같이 2020년 137억 달러로 추정 된다. 이 중 시설투자(64.9억 달러)에서 유틸리티분야가 차 지하는 비율은 $90.8 \%$ (58.9억 달러), 고순도 공업용수분야 는 $9.2 \%$ (6.0억 달러)이며, 운영분야(60.5억 달러)에서 유틸 리티분야가 차지하는 비율은 $79.4 \%$ (48.1억 달러), 고순도 공업용수 분야는 $20.6 \%$ (12.5억 달러)이다(GWM 2018). ${ }^{17)}$

국내 고순도 공업용수분야의 시설투자비 5.97억 달러 중 전자 분야(Microelectronics)가 $37.5 \%$ 로 가장 큰 비중을 차지하고, 식음료(Food \& Beverage) 21.0\%, 발전(Power Generation) 9.7\%, 석유정제(Refining\& petrochemicals) $1.3 \%$, 의약품(Pharmaceuticals) 이 $1.0 \%$ 를 차지한다.

고순도 공업용수의 사용 비율은 반도체, $\mathrm{LCD}$, 태양광 패널 등 분야별 초고순도 공업용수, 고순도 공업용수, 침전수 사용 비율을 구분 적용한다. 사용비율은 "K-water 공업(산업)용수 시장분석 및 효율적 공급방안(2010)" 내부 용역 수행 시 조사 된 40개 개별업체의 용도별 사용비율 조사결과 ${ }^{18)}$ 와 "K-water 순수 및 초순수 기반기술 조사분석(2011)” 내부 용역에서 현 지 조사한 44개 Plant에 대한 용도별 사용비율을 종합적으로 고려하여 Table 9와 같이 산정하였다. 용수 중 고순도 공업용 
Table 10. Prediction of UPW and high pure water demand in Korea. ${ }^{19)}$

\begin{tabular}{ccccc} 
Division & & \multicolumn{3}{c}{ Water demand $\left(\mathrm{m}^{3} / \mathrm{d}\right)$} \\
\cline { 2 - 5 } & Total & $\begin{array}{c}\text { Ultrapure water } \\
(10 \mathrm{M} \Omega \cdot \mathrm{cm} \uparrow)\end{array}$ & $\begin{array}{c}\text { Pure water } \\
(10 \mathrm{M} \Omega \cdot \mathrm{cm} \downarrow)\end{array}$ & $\begin{array}{c}\text { Industrial water } \\
2010\end{array}$ \\
\cline { 2 - 5 } & $4,437,885$ & 301,459 & 348,069 & $3,788,357$ \\
\hline 2015 & $6,391,358$ & 481,924 & 491,286 & $5,418,148$ \\
\hline 2020 & $7,228,606$ & 496,745 & 539,191 & $6,192,670$ \\
\hline
\end{tabular}

Table 11. Scale of industrial water market by use. ${ }^{19)}$

\begin{tabular}{|c|c|c|c|c|c|}
\hline \multirow{2}{*}{\multicolumn{2}{|c|}{$\begin{array}{l}\text { Division } \\
\text { (year) }\end{array}$}} & \multirow{2}{*}{$\begin{array}{l}\text { Demand } \\
\left(\mathrm{m}^{3} / \mathrm{d}\right)\end{array}$} & \multicolumn{3}{|c|}{ Current state of market (Unit : $10^{8} \mathrm{~W}$ ) } \\
\hline & & & Investment expenditure & Operating expenditure & Total \\
\hline \multirow{3}{*}{$\begin{array}{l}\text { Total } \\
(a+b)\end{array}$} & 2010 & 649,528 & 6,880 & 3,468 & 10,348 \\
\hline & 2015 & 973,210 & 10,555 & 5,256 & 15,811 \\
\hline & 2020 & $1,035,936$ & 11,103 & 5,562 & 16,665 \\
\hline \multirow{3}{*}{$\begin{array}{l}\text { Ultrapure water } \\
\text { (a) }\end{array}$} & 2010 & 301,459 & 4,508 & 1,931 & 6,439 \\
\hline & 2015 & 481,924 & 7,206 & 3,086 & 10,292 \\
\hline & 2020 & 496,745 & 7,428 & 3,181 & 10,609 \\
\hline \multirow{3}{*}{$\begin{array}{l}\text { Pure water } \\
\text { (b) }\end{array}$} & 2010 & 348,069 & 2,373 & 1,537 & 3,910 \\
\hline & 2015 & 491,286 & 3,349 & 2,169 & 5,518 \\
\hline & 2020 & 539,191 & 3,675 & 2,381 & 6,056 \\
\hline
\end{tabular}

* Facility investment and operating expenditure were applied with the average price analyzed through domestic market surveys.

- Ultrapure water : Facility investment expenditure 1,524,000 $\mathrm{W} / \mathrm{m}^{3}$, Operating expenditure $1,755 \mathrm{~W} / \mathrm{m}^{3}$

- Purity water : Facility investment expenditure $722,000 \mathrm{H} / \mathrm{m}^{3}$, Operating expenditure 1,210 $\mathrm{W} / \mathrm{m}^{3}$

Table 12. Market share of domestic industrial water company (2017). ${ }^{20)}$

\begin{tabular}{ccccc} 
Division & Veolia & HTS & HUVIS WATER & K-Water \\
Sales $(\forall m)$ & 231,201 & 87,489 & 82,896 & 30,676 \\
\hline Share $(\%)$ & 45.5 & 17.2 & 16.3 & 6.0 \\
\hline
\end{tabular}

* Other : Powell (5.0\%), Hanju (3.1\%), West sea water (3.0\%), Dreampia (2.4\%), SWROGuangyang (2.3\%)

수의 사용 비중이 높은 제조업은 아래 표와 같이 반도체와 $\mathrm{LCD}$ 산업이다. ${ }^{19}$

순수 및 초순수 용도별로 산정된 사용 비율은 2025 수도정 비기본계획상의 전국 471 개 산업단지의 장래 공업용수 수요 량을 반영하여 산정하였으며, Table 10에서 볼 수 있듯이 각 초순수 수요량은 2010년 301천 $\mathrm{m}^{3} /$ 일에서 2020년 497천 $\mathrm{m}^{3} /$ 일 으로 약 $65 \%$ 의 증가가 예상되며, 순수 수요량은 2010년 348

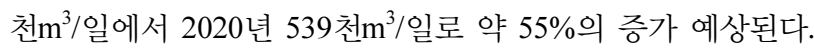
순수 및 초순수 시장분석을 위해 시설투자비와 운영비로 구분하였으며, 각 원단위는 "K-water 순수 및 초순수 기반 기술 조사분석 (2011)” 용역 수행시 현지 조사한 44개 Plant 조사결과를 활용하였다. 조사결과를 바탕으로 초고순도 공 업용수의 경우 시설투자비 1,524 천원 $/ \mathrm{m}^{3}$, 및 운영비 1,755 원 $/ \mathrm{m}^{3}$ 를 적용하여 계산하였으며, 고순도 공업용수는 시설투자 비 722 천원 $/ \mathrm{m}^{3}$, 운영비 1,210 원 $/ \mathrm{m}^{3}$ 을 적용하였다. ${ }^{19)}$

결과적으로 고순도 공업용수(초고순도 공업용수 포함) 시
설투자 및 운영 시장은 Table 11과 같이 2010년 10,348억원 에서 2020년 16,665 억원으로 약 $61 \%$ 증가되며, 그 중 시설 투자비의 경우 2010년 6,880억원에서 2020년 1조 1,103억 원으로 증가하고, 운영비는 2010년 3,468억원에서 2020년 5,562 억원으로 증가된다.

2017년 기준 국내 고순도 공업용수 위탁 운영시장 전체 매출액은 약 5,082 억원으로 추정된다. 위탁시장에 대한 조 사는 별도의 용역으로 조사된 자료는 없으며, 위탁시장에 참여중인 대상기업들의 매출액을 ${ }^{20)}$ 조사하여 시장규모를 추 산하였다. 조사대상은 국내 고순도 공업용수 운영시장 중 연매출액 100 억원 이상 업체 대상, 폐수처리업 및 기업 자체 운영 중 사업장은 미포함 되었으며 삼성 등 매출액 자료 확보 곤란한 기업도 미포함 되었다. 매출액 기준 다국적 물기업인 베올리아의 점유율이 약 $46 \%$ 로 가장 높으며 베올리아와 $\mathrm{HTS}$ 를 합하면 $63 \%$, K-water는 약 $6 \%$ 수준이다. Table 12은 '17년 기준 국내 고순도 공업용수 위탁운영 시장 주요업체 


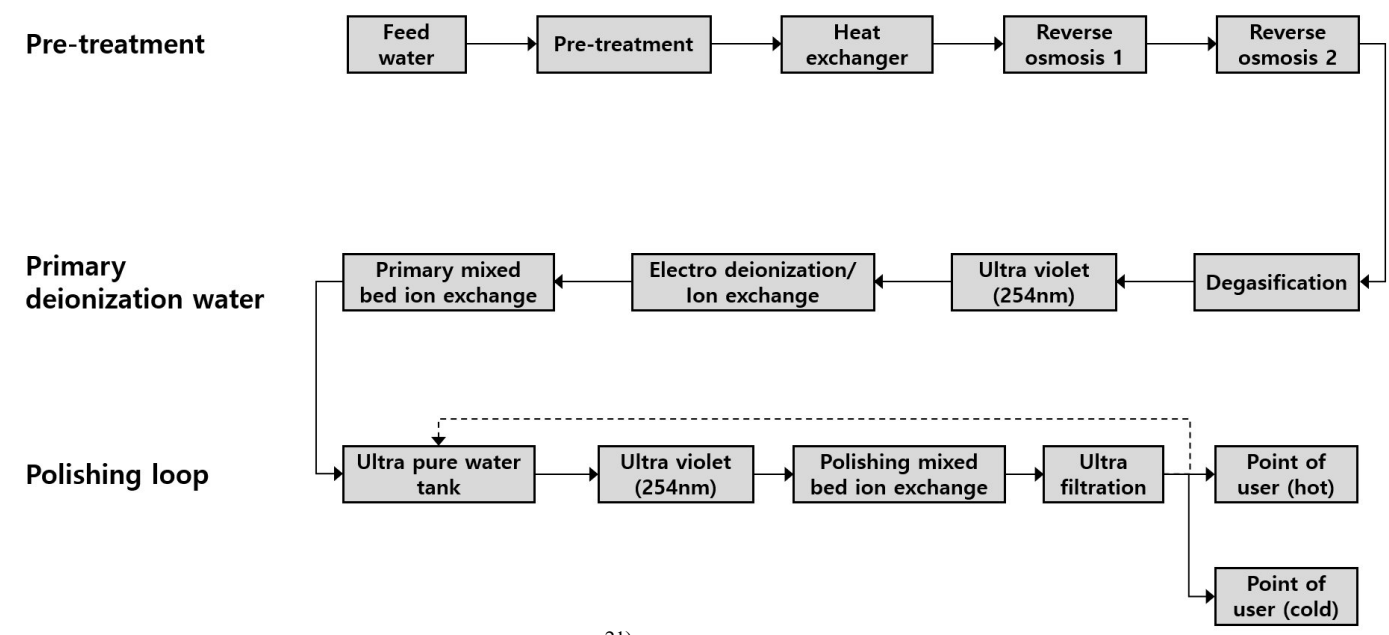

Fig. 4. Example of ultrapure water production process. ${ }^{21)}$

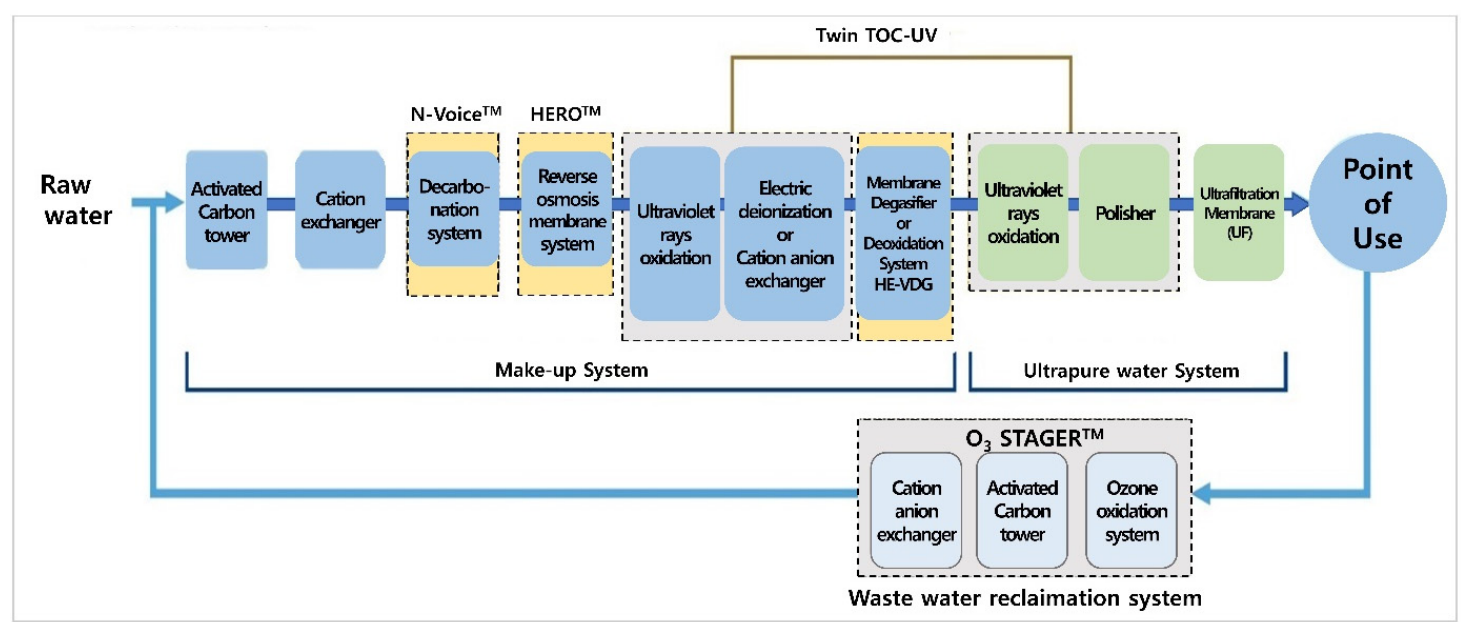

Fig. 5. Ultrapure water production process of Nomura (Japan). ${ }^{22)}$

점유율 현황을 나타내고 있다.

\section{3. 초순수 공정 개요 및 설계 기술동향}

\section{1. 초순수 공정의 일반적인 구성}

초순수를 제조하기 위해서는 원수 중에 포함되어 있는 다 양한 종류의 오염물질을 최대한 제거함으로써 반도체 제조 공정 등에서 필요로 하는 수질을 만족시킬 수 있어야 한다. 또한 극미량의 오염물질이라도 유입되는 경우 생산된 반도 체의 품질을 저하시키나 수율을 낮출 수 있기 때문에 항상 안정적인 생산수의 수질을 유지할 수 있어야 한다. 이러한 요구사항들을 만족시키기 위하여 초순수 제조공정은 일반 적인 수처리 공정과는 다른 구성을 가지고 있다.

초순수 제조공정은 Fig.4와 같이 전처리(Pretreatment), 순 수제조(Primary DI), 수질조정(Polishing loop)의 3단계로 구 분할 수 있다. 전처리 단계에서는 여과와 역삼투 공정을 조 합하여 입자성 물질과 용존 물질을 주로 제거하며, 순수제 조 단계에서는 탈기와 UV 산화, 이온교환(또는 전기탈이온)
등을 조합함으로써 용존기체와 함께 전처리 단계에서 제거 되지 않고 잔류하고 있는 용존 이온과 유기물 등을 제거하 게 된다. 마지막으로 수질조정 단계에서는 UV 산화와 이온 교환, UF 등을 조합하여 미량으로 남아있는 물 속의 오염물 질을 추가적으로 제거함으로써 반도체 생산공정에 적합한 수질이 만들어진다.

Fig.4에 제시된 공정은 하나의 사례일 뿐이며, 실제 초순 수 제조공정은 생산수의 수질목표와 반도체의 집적도, 반도 체 제조공정의 종류 등에 따라서 다르게 구성될 수 있다. 또 한 최근에는 외부 수원에서 유입하는 원수의 양을 감소시키 기 위하여, 초순수 사용 후 발생하는 폐수를 다시 재이용하 는 방법이 적용되고 있는 추세이다.

초순수 제조 시스템을 공급하는 주요 회사의 공정은 앞서 설명한 구성과 전체적으로 큰 차이점이 없다. 그러나 개별 단위공정에는 다소 차이점이 있으며 세부 구성이 상이한 경 우도 있다. Fig. 5는 일본 Nomura사의 초순수 제조공정의 구성이며, 고회수율의 역삼투 공정 구성을 위하여 $\mathrm{HERO}^{\circledR}$ 공정을 채택하고 있으며, 그 외 N-Voicer ${ }^{\circledR}$ 와 HE-VDG 등의 


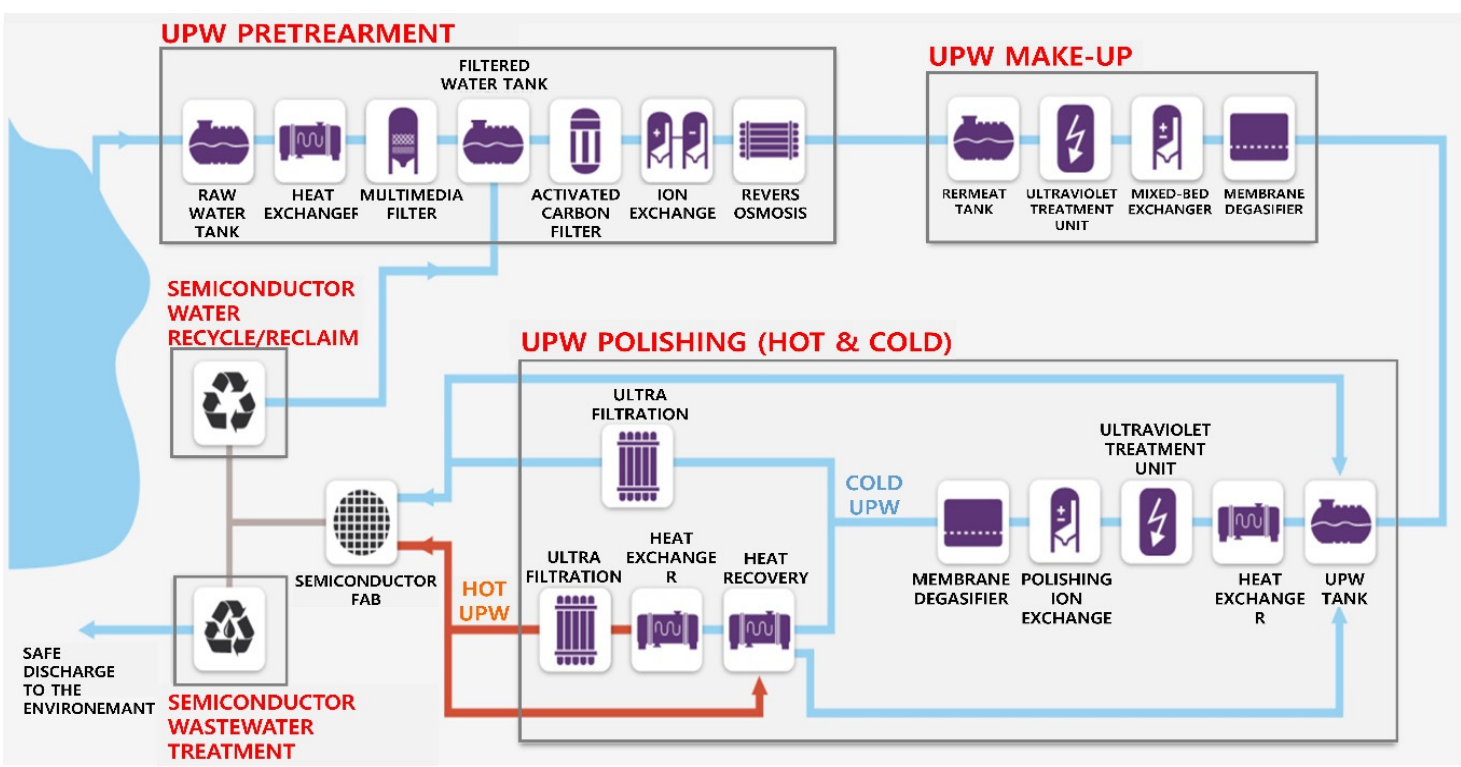

Fig. 6. Ultrapure water production process of Ovivo (Germany). ${ }^{23)}$

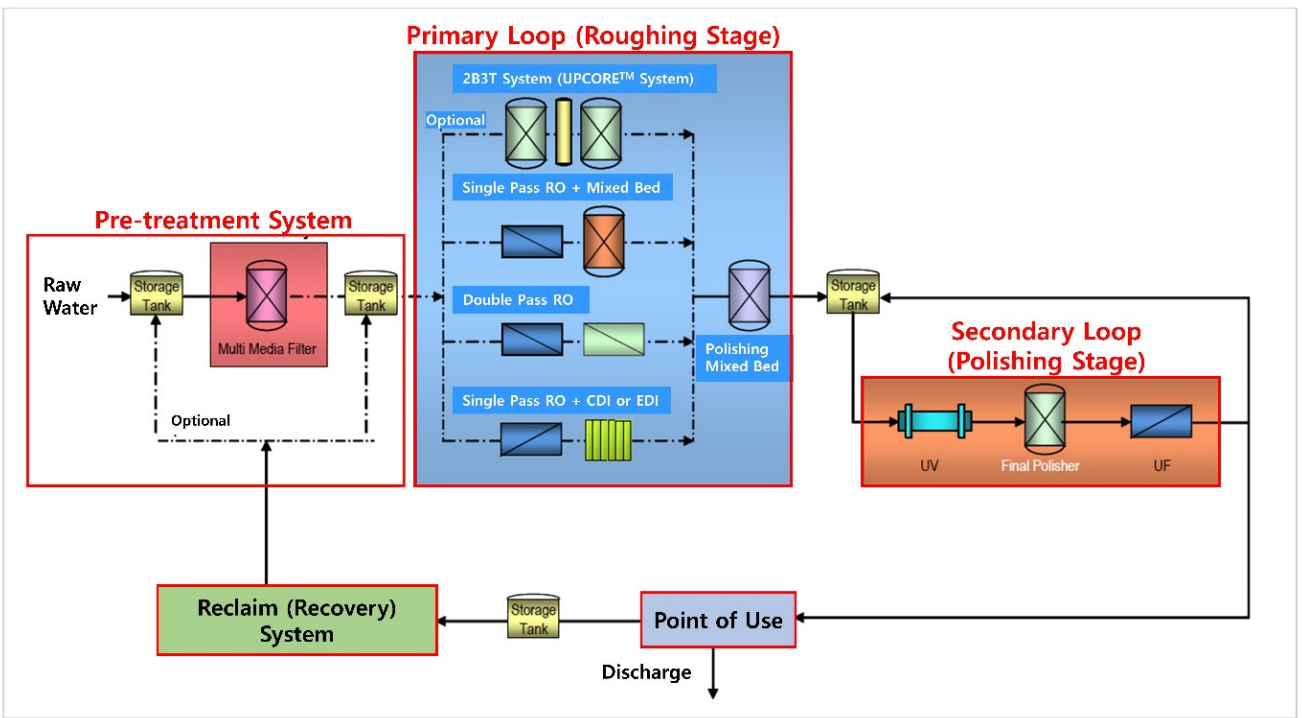

Fig. 7. Ultrapure water production process of DuPont (USA). ${ }^{24)}$

특정 단위공정을 적용하고 있는 것을 알 수 있다. 또한 사용 한 후 발생한 폐수의 재이용을 위하여 $\mathrm{O}_{3} \mathrm{STAGER}^{\circledR}$ 라는 공 법을 적용하고 있다.

Fig. 6은 독일 Ovivo사의 초순수 제조공정을 보여주고 있 다. 전체적인 구성은 Nomura사의 공정과 유사하나 전처리 의 구성방법과 개별 단위공정의 종류도 다소 차이가 있는 것으로 나타나고 있다. 한편 미국 Dupont사의 초순수 제조 공정의 경우 Fig. 7에 나타난 바와 같이 자체적으로 개발한 역삼투막과 이온교환 수지 등을 사용하고 있다.

\section{2. 제거대상 물질 별 기술 동향}

\subsection{1. 용존 무기물}

원수 중의 용존 무기물은 주로 이온이며, 일정 농도 이상이
유입되는 경우 반도체 제조공정에서 여러 가지 문제를 발생 시키게 된다. 따라서 반도체 공정을 위한 초순수는 전기저항 을 $18 \mathrm{M} \Omega \cdot \mathrm{cm}$ 이상으로 만들어야 하며, 이를 위하여 용존 무기물의 농도를 극단적으로 낮추어야 한다. 또한, 암모니아, 염소, 인산, 알루미늄, 보론, 칼슘 등의 특정 이온의 농도도 반도체 제조공정에 따라 지정된 값 이하로 낮추어야 한다.

용존 무기물의 제거를 위해서는 주로 역삼투 공정과 이온 교환수지가 사용된다. 역삼투 공정은 이온제거에 효과적인 방법이나 단독으로는 초순수 생산에서 요구되는 수질을 얻 을 수 없어 다시 한 번 역삼투 처리를 하고(Two pass system), 이온교환수지를 이용하여 남은 이온을 추가적으로 처리한다. 여기에 사용되는 역삼투막은 주로 BWRO (Brackish Water Reverse Osmosis) 막이 사용되며, $\mathrm{NaCl}$ 제거율은 $99.0 \%$ 에서 


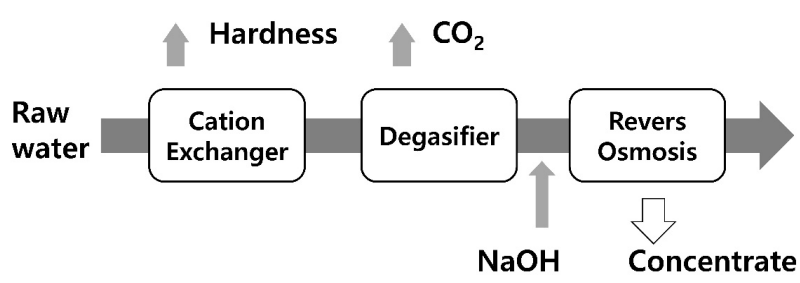

Fig. 8. Flow chart of high efficiency RO process.

$99.7 \%$ 사이의 값을 가진다. ${ }^{24,25)}$ 초순수 제조에 널리 사용되는 역삼투 공법으로는 $\mathrm{HERO}^{\circledR}$ (High efficiency reverse osmosis) 가 있으며, 이 방법은 역삼투의 전단계로 양이온 교환수지와 탈탄산 장치를 배치하여 탄산염에 의한 스케일 형성을 억제 한 후 $\mathrm{pH}$ 를 높여 실리카와 보론의 제거율을 높이고 높은 회 수율로 역삼투 공정을 운전할 수 있는 기술이다. ${ }^{25)}$ Nomura사 가 개발하였으며 $\mathrm{HERO}^{\circledR}$ 공정은 기존 역삼투 공정보다 실리 카 및 보론 제거 효율을 향상시킨 공정이다. 본 기술은 Fig. 8과 같이 양이온 교환기, 탈기 장치와 높은 $\mathrm{pH}(>10)$ 에서 운 전되는 역삼투 분리막 공정으로 구성된다.

각 단위 공정은 경도(양이온 교환수지), 이산화탄소(탈기 장치)와 이온(역삼투 분리막)을 고회수율(90 98\%) 조건에 서 제거하게 된다. 기존 역삼투 공정에서 실리카나 보론과 같은 약이온화 종들의 제거율은 중성 $\mathrm{pH}$ 조건하에 제한적 이지만 본 시스템은 알칼리 조건에서 역삼투공정을 운전하 여 높은 실리카 및 보론 이온 제거율을 달성한다. 실제로 기 존 RO 공정의 제거율과 비교하였을 때 본 시스템을 통해 실리카 제거율은 $99 \%$ 에서 $99.9 \%$, 보론 제거율은 $70 \%$ 에서 $98.5 \%$, 유기물 제거율은 $95 \%$ 에서 $99.7 \%$ 로 향상되는 결과 를 나타내었다. ${ }^{26)}$

최근에는 이온교환수지 대신 전기탈이온(Electro deionization, $\mathrm{EDI}$ )이 널리 적용되고 있다. ${ }^{27)} \mathrm{EDI}$ 는 이온교환공정의 단점을 보완한 신기술로 전기투석 장치의 이온교환막 사이에 이온교 환수지를 충진하여 이온을 제거하는 기술이다. EDI는 이온교 환수지 재생을 위해 시스템을 중단시킬 필요가 없어 연속적인 초순수 생산이 가능하며, 재생폐수가 발생하지 않는 장점을 가지고 있다. 초순수 공정에 사용되는 $\mathrm{EDI}$ 의 예로서 $\mathrm{DuPont}^{\mathrm{TM}}$ 의 $\mathrm{EDI}-310$ 등이 있다.

\subsection{2. 유기물}

원수 중에 포함되어 있는 비교적 분자량이 큰 유기물은 대 부분 전처리와 역삼투 공정에서 제거된다. 그러나 용존 유기 물 중 urea, trihalomethane (THM), isopropyl alcohol (IPA) 등 은 TOC (Total organic carbon) $1 \mu \mathrm{g} / \mathrm{L}$ 미만의 농도까지 제거 하기가 쉽지 않다. 이러한 유기물이 초순수에 포함되면 반도 체 공정 단계에서 수율과 장치 성능에 영향을 미치는 것으로 알려져 있으므로, 이를 제거하기 위한 추가적인 공정이 필요 하며 주로 UV 산화와 고도산화처리(Advanced oxidation process, $\mathrm{AOP}$ )가 활용된다. 수중의 urea 제거를 위해서는 UV
(Ultraviolet)와 persulfate를 조합한 방법이 효과적이라는 연 구결과가 있으며 ${ }^{28}$, IPA와 메탄올의 제거에는 $185 \mathrm{~nm}$ 파장의 $\mathrm{UV}$ 와 이온교환 수지를 조합한 방법이 효과적이라는 연구결 과가 보고된 바 있다. ${ }^{29)}$ 한편, 상용화된 기술로서 Evoqua의 Vanox AOP 기술은 처리수의 $\mathrm{TOC}$ 를 $0.5 \mu \mathrm{g} / \mathrm{L}$ 이하로 안정 적으로 유지할 수 있는 것으로 발표되었다. ${ }^{30)}$

최근에는 역삼투 공정에서도 유기물 제거율을 높이기 위한 새로운 막이 개발되어 적용되고 있다. 예를 들어 FILMTEC 의 SG30LE막은 IPA 제거율이 $92 \%$ 이며, 이는 일반적인 BWRO (Brackish reverse osmosis)막인 BW30LE의 86\%에 비해 높은 제거율을 나타낸다. 역삼투 공정에서 유기물을 추가적으로 제거할 수 있으면 후단의 $\mathrm{AOP}$ 공정에서의 부담을 줄일 수 있으므로 보다 경제적이고 안정적인 유기물의 처리를 가능 하게 할 수 있다. ${ }^{24)}$

\subsection{3. 입자}

초순수 내의 입자가 포함되는 경우 반도체 웨이퍼 표면에 수많은 형태의 결함이 발생하게 된다. 따라서 입자의 제거 는 초순수 공정에서 중요한 기능 중 하나이다. 초순수 내에 유입되는 입자의 수준은 나노미터 크기로 제어해야 하며 이 를 위하여 여과공정이 본 공정에 사용되지만 추가적인 입자 오염이 유발될 수 있으므로 사용하기 전에 추가적인 여과를 하게 된다.

입자 제거를 위하여 사용되는 필터는 유기물 또는 이온의 유출이 없는 소재로 구성된 것이어야 하며, 신뢰성과 성능 을 보장하기 위해 사용 전에 완결성 테스트를 거쳐야 한다. 필터의 소재로는 나일론, 폴리에틸렌, 폴리설폰 및 불소계 고분자 등이 사용되고 있으며, 초순수 공정에서 사용하기 위해 접착제 또는 기타 오염 첨가제를 사용하지 않고 열 용 접을 한다. 필터의 미세 다공성 구조는 입자를 제거하는 기 능과 밀접한 연관성이 있으며, 평균적인 세공 크기뿐 아니 라 세공크기의 분포도 중요하다. 여러 종류의 필터 중에서 중공사막으로 구성된 한외여과막(Ultrafiltration membrane, $\mathrm{UF}$ )이 현재 널리 사용되고 있다. UF는 초순수를 위한 효율 적인 여과 기술이며 카트리지 필터에 비하여 수명이 길고 나노 미터 크기의 입자에 대한 제어가 가능하다. 여기에 적 용되는 UF는 분획분자량이 $6,000 \sim 10,000$ Dalton 정도이 며, 이는 $10 \mathrm{~nm}$ 이상의 입자를 제거할 수 있는 세공 크기에 해당한다. ${ }^{31}$

\subsection{4. 용존 기체}

원수 중에는 질소, 산소, 이산화탄소 등의 기체가 용존 상 태로 존재하고 있으며, 일반적인 수처리 방법으로는 잘 제 거되지 않는다. 용존 기체는 리소그래피 공정 중에서 압력 차이에 의하여 공기방울을 형성할 수 있으며, 이는 웨이퍼 위에 부착되어 패턴의 현상을 방해하고 결함을 만들게 된 
다. 또한 반도체 세정공정에서도 초순수 내에 공기방울이 존재하면 웨이퍼 표면에 부착되어 세정효과를 떨어뜨릴 수 있다. 한편 용존 산소의 경우 웨이퍼 표면에 산화막을 형성 하여 공정에 영향을 줄 수 있으며, 이온교환 수지를 산화시 켜 수명을 단축시키며, 배관이나 장치 내에서의 박테리아 번식을 촉진시킬 수 있다. 따라서 용존 기체의 제거는 초순 수 공정에서 중요한 단계 중 하나이다.

용존 기체의 탈기기술로는 탈탄산법(DG, Degassing), 진 공탈기법(VDG, Vacuum degassing), 고효율 진공탈기법 (HE-VDG, High efficiency vacuum degassing), 막 탈기법 (MDG, Membrane degassing) 등이 있다. 탈탄산법은 이산화 탄소만 제거할 수 있으며, 진공탈기법은 산소와 이산화탄소 를 같이 제거할 수 있으나 처리수 내 용존산소의 농도가 높 은 편이다. 반면에 고효율 진공탈기는 산소와 이산화탄소를 모두 제거할 수 있으며 용존산소의 농도를 낮출 수 있어 반 도체 공정에 적합한 방법 중 하나이다. 그러나, 시설의 높이 가 $15 \mathrm{~m}$ 이상으로 별도의 설치공간이 필요한 단점이 있다. 한편, 막 탈기법은 소수성 중공사 기체투과막을 이용하는 방법으로 ${ }^{32)}$ 타 공법에 비하여 집적도가 높으며, 단시간내에 정상운전이 가능하며, 운전 및 장치가 간단하여 자동화가 쉬울 뿐 아니라 용존 기체의 제거율이 비교적 안정적이며 적용범위가 넓다는 장점을 가진다. ${ }^{33)}$ 대표적인 막탈기 모듈 로는 $3 \mathrm{M}$ 사의 Liqui-Cel 중공사막이 있다.

\subsection{5. 기타 오염물질}

반도체 소자가 집적화됨에 따라서 초순수 내 미량으로 존 재하는 과산화수소 $\left(\mathrm{H}_{2} \mathrm{O}_{2}\right)$ 에 의한 반도체 웨이퍼의 산화 문
제가 점차 심각해지고 있다. 이를 방지하기 위해서는 $\mathrm{H}_{2} \mathrm{O}_{2}$ 의 농도를 $1 \mu \mathrm{g} / \mathrm{L}$ 이하로 낮추어야 한다. Kurita에서는 $\mathrm{H}_{2} \mathrm{O}_{2}$ 의 농도 저감을 위하여 2008년에 특수한 필러를 이용한 Nanosaver ${ }^{\mathrm{TM}}$ 라는 기술을 개발하였다. ${ }^{34)}$

\section{3. 초순수 공정의 설계와 검증}

반도체의 집적도가 높아짐에 따라서 반도체 제조공정에 서는 더 높은 순도를 가지는 초순수를 필요로 하게 된다. ${ }^{31)}$ 반도체 제조에 사용되는 초순수는 용존 이온, 입자, 유기물, 미생물, 실리카 등의 농도가 0 에 근접해야 한다. 실제로 현 재 반도체용 초순수는 일반적으로 $25^{\circ} \mathrm{C}$ 에서 전기저항이 $18.2 \mathrm{M} \Omega \cdot \mathrm{cm}$ 이상(전기 전도도 $0.055 \mu \mathrm{S} / \mathrm{cm}$ 이하)이어야 하며 이온성 및 비이온성 오염물질은 검출한계 이하로 존재 하여야 한다. 초순수의 세부적인 규격은 반도체 공정의 종 류별로 ASTM에 제시되어 있으며 ${ }^{10)}$, 초순수 공정을 설계할 때는 이러한 목표 수질을 달성하기 위하여 다수의 단위공정 을 조합해야 한다. ${ }^{35)}$ 또한 초순수 공정에서는 단순한 처리 효율 뿐 아니라 처리 수질의 안정성이 중요하므로, 이를 달 성하기 위한 방법이 설계에 반영되어야 한다. 추가적으로 온라인 계측장치와 연동하여 항상 수질을 감시하고 제어할 수 있는 방안도 같이 마련되어야 한다. 따라서 초순수 공정 의 효율적인 설계를 위해서는 다양한 공정의 조합에 대하여 그 성능을 검증할 수 있는 파일럿 규모의 평가시설을 자체 적으로 보유하는 것이 필요하다.

초순수 공정의 검증은 아래 Fig.9와 같이 반드시 리스크 기반의 전과정적 접근법(risk-based lifecycle approach)을 활 용해야 한다. ${ }^{36)}$ 이 접근방법은 설계 및 개발, 적격성 및 지

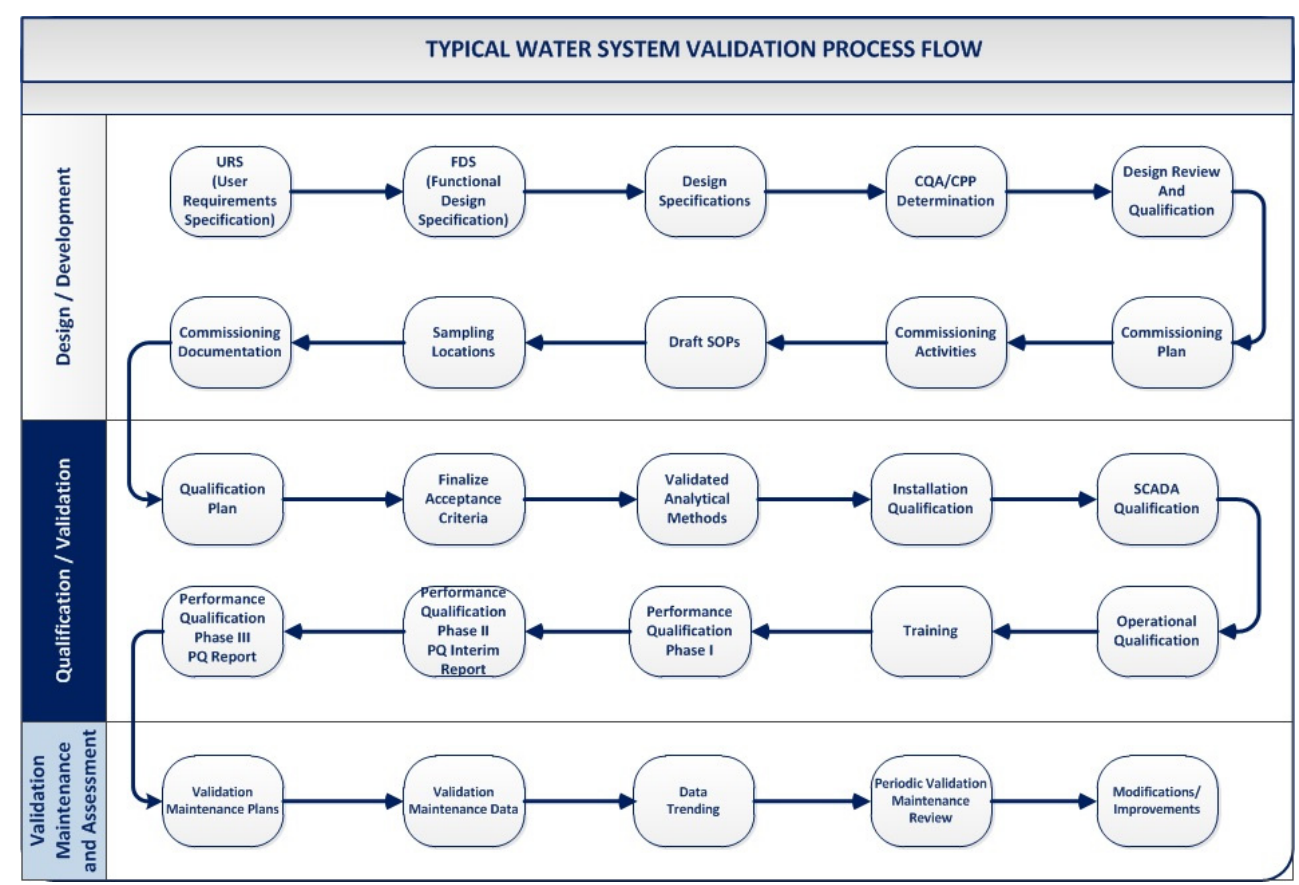

Fig. 9. Typical water system validation process flow. ${ }^{36)}$ 
Table 13. Feature of reverse osmosis membrane for ultrapure water production by manufacturers.

\begin{tabular}{|c|c|c|c|c|c|c|c|c|}
\hline Manufacturers & Model & $\begin{array}{c}\text { Area of } \\
\text { membrane } \\
\left(\mathrm{m}^{2}\right)\end{array}$ & $\begin{array}{l}\text { Flow rate } \\
\left(\mathrm{m}^{3} / \mathrm{d}\right)\end{array}$ & $\begin{array}{l}\text { Removal } \\
\text { efficiency } \\
(\%)\end{array}$ & $\begin{array}{l}\text { Maximum } \\
\text { pressure } \\
\text { (bar) }\end{array}$ & $\begin{array}{c}\text { Maximum } \\
\text { temperature } \\
\left({ }^{\circ} \mathrm{C}\right)\end{array}$ & $\mathrm{pH}$ & $\begin{array}{c}\text { Residual } \\
\text { Chlorine } \\
\text { (mg/L) }\end{array}$ \\
\hline Filmtec & SG30LE-400 & 37.0 & 37.0 & 99.5 & 41 & 45 & $2-11$ & 0.1 \\
\hline TORAY & SU-720 & 27.8 & 26.0 & 99.4 & 20 & 45 & $2-10$ & - \\
\hline Hydranautics & CPA5-LD & 37.1 & 41.4 & 99.7 & 41 & 45 & $2-11$ & 0.1 \\
\hline LG Chem & LG BW 400 ES & 37.0 & 39.7 & 99.6 & 41 & 45 & $2-11$ & 0.1 \\
\hline Trisep & HP 8040 & 35.2 & 43.0 & 99.5 & 41 & 50 & $1-12$ & 0.1 \\
\hline
\end{tabular}

Table 14. Feature of ultra filtration membrane for ultrapure water production by manufacturers.

\begin{tabular}{cccccccccc} 
Manufactures & Model & $\begin{array}{c}\text { Filtration } \\
\text { Media }\end{array}$ & Flux (LMH) & $\begin{array}{c}\text { Pore } \\
\text { size } \\
(\mu \mathrm{m})\end{array}$ & $\begin{array}{c}\text { Max. } \\
\text { injection } \\
\text { pressure } \\
(\text { bar })\end{array}$ & $\begin{array}{c}\text { Limited } \\
\text { operational } \\
\text { temperature } \\
\left({ }^{\circ} \mathrm{C}\right)\end{array}$ & $\begin{array}{c}\text { NaOCl Conc. } \\
\text { (mg/L) }\end{array}$ & $\begin{array}{c}\text { Membrane } \\
\text { module }\end{array}$ \\
\hline Asahi Kasei & OLT-6036H & PS & $>470$ & 6,000 Da & 9 & 30 & Hollow fiber \\
\hline Filmtec & DW74-1100 & PVDF & $40-105$ & 0.03 & 5 & 40 & 2,000 & Spiral wound \\
\hline GE & JW2540C-50P & PVDF & $8-34$ & - & 6.9 & 50 & $5,000^{*}$ & Spiral wound \\
\hline Hydrana-utics & HYDRAcap-80 & PES & $34-110$ & 0.08 & 5 & 40 & Spiral wound \\
\hline Toray & HFS-2020 & PVDF & 36 & 0.02 & 3 & 40 & 2,000 & Hollow fiber \\
\hline Trisep & UB70 & PVDF & 394 & 0.03 & - & - & 2,000 & Spiral wound \\
\hline
\end{tabular}

*ppm-days

속적인 검증의 3 단계로 구성된다. 따라서 초순수 공정의 설 계 및 설치 후에도 이를 검증하기 위한 여러 단계를 거쳐야 하며, 최종적으로 신뢰성을 확인한 후에 이를 현장에서 활 용할 수 있다.

\section{4. 초순수 제조용 핵심 소재 기술 동향}

\section{1. 막소재}

\subsubsection{RO (Reverse osmosis)}

초순수 공정에서 대표적으로 사용되는 역삼투 분리막은 폴리아마이드(Polyamine, PA) 기반 박막 복합 분리막이다. 1990년 이전에는 셀룰로스(Cellulose acetate, CA) 계열의 분 리막이 주를 이루었지만 미생물에 의해 생분해되거나 $\mathrm{pH}$ 변화에 따라 쉽게 가수분해되어 막 성능이 저하되는 단점으 로 인해, 우수한 내구성, 높은 수투과도 및 염 제거율을 가 진 PA 계열 고분자를 초순수 공정에서 주요 소재로 사용하 고 있다. ${ }^{25}$ 초순수 생산을 위한 상용 역삼투 분리막의 주요 제조사 및 세부 분리막 특징은 Table 13과 같이 정리하였다.

\subsubsection{UF}

초순수 생산공정에서 한외여과 분리막 공정은 최종 단계에 적용되며 배관 및 탱크에서 발생할 수 있는 미세 입자성 물질 을 최종 제거하는 목적으로 설치한다. 현재까지 수처리 분리 막 시장은 고분자 소재가 대부분을 차지하고 있으며 대표적 인 고분자 분리막 소재로는 불소계(PVDF (polyvinylidene fluoride), PTFE (polytetrafluoroethylene)), 설폰계(PES (polysulfone)), 그리고 올레핀계(PE (polyethylene), PP (polypropylene))가 있다. 현재 초순수 생산용으로 사용되고 있는 고분자 소재 한외여과 분리막의 주요 제조사 및 막특성 은 Table 14와 같다.

최종 한외여과막의 경우 대부분 PVDF 계열의 소재가 사용 되고 있으며, 유입 압력 및 한계 운전 온도는 분리막 모듈 형태 및 재질에 따라 서로 상이하다. 초순수 시스템에서 Asahi Kasei사의 OLT 시리즈 제품이 반도체 제조용 초순수 와 배출수 회수 프로세스의 표준 설비로 자리매김했으며, 전 세계 반도체 업체에서 사용되고 있다.

\section{2. 흡착소재}

\subsection{1. 이온교환수지}

초순수 공정을 목적으로 현재 사용되고 있는 이온교환수지 는 대부분 합성수지로, 고분자 매트릭스로 스티렌(Styrene) 에 디비닐벤젠(Divinyl benzene, DVB,)을 가교제로 사용하여 3 차원의 망상구조를 가진 수지를 가장 널리 사용하고 있다. 초순수 공정에 따라 1 차 순수 처리 공정에서는 일반 정수시 스템과 유사한 이온교환수지가 사용되며 2차 초순수 처리 공 정에서는 이온교환수지에서 불순물 이온 탈착을 방지하기 위하여 재생된 형태의 특수 후처리된 이온교환수지가 사용 되고 있다. 현재 양산되고 있는 초순수 공정용 이온교환수지 의 주요 제조사 및 제품 특징을 Table 15와 같다. 
Table 15. Feature of ion exchange resin for ultrapure water production by manufacturers.

\begin{tabular}{cccccccc} 
Manufacturers & Model & \multicolumn{2}{c}{ lon exchange capacity $(\mathrm{eq} / \mathrm{L})$} & Polymer & Functional group \\
\cline { 3 - 6 } Dowex & MR-575 LC NG & 1.9 & 1.0 & Styrene-DVB, gel & $\begin{array}{c}\text { Sulfonic acid, } \\
\text { Quaternary amine }\end{array}$ & Mixed Resin \\
\hline Rohm \& Haas & UP6150 & $>1.8$ & $>1.0$ & Styrene-DVB, gel & Anion $\left(\mathrm{HH}^{+}\right)$ & & Mixed Resin \\
\hline Mitsubishi & UBKN1U & 2.4 & - & Styrene-DVB, gel & Sulfonic acid & Strong acid cation \\
\hline Samyang & UPRM200 & $>2.0$ & $>1.1$ & Polystyrene + DVB & $\begin{array}{c}\text { Sulfonic acid, } \\
\text { Trimethylamine }\end{array}$ & Mixed Resin \\
\hline
\end{tabular}

* ppm-days

Table 16. A Trend in research on the electro-deionization (EDI) technology applied to ultrapure water.

\begin{tabular}{|c|c|c|c|c|c|c|}
\hline Process & $\begin{array}{l}\text { Injection conc. } \\
\text { (TDS, ppm) }\end{array}$ & $\begin{array}{l}\text { Removal efficiency } \\
(\%)\end{array}$ & $\begin{array}{l}\text { Ion exchange membrane } \\
\text { media }\end{array}$ & lon exchange resin & Electrode & Reference \\
\hline \multirow{6}{*}{ EDI } & 3.5 & 99.6 & - & - & - & [39] \\
\hline & 7.5 & 96.0 & $\begin{array}{l}\text { Cation : Selemion CME } \\
\text { Anion : Selemion AME }\end{array}$ & $\begin{array}{l}\text { Cation : Purolite CT } 175 \\
\text { Anion : Purolite A } 500\end{array}$ & - & [40] \\
\hline & 12.8 & 99.6 & - & - & - & [37] \\
\hline & 13.1 & 97.6 & $\begin{array}{l}\text { Cation : Neosepta CMX } \\
\text { Anion : Neosepta AMX }\end{array}$ & $\begin{array}{l}\text { Cation : Amberlite IRN77 } \\
\text { Anion : Amberlite IRN78 }\end{array}$ & - & {$[41]$} \\
\hline & 12.8 & 99.5 & $\begin{array}{l}\text { Cation : Neosepta CMX } \\
\text { Anion : Neosepta AMX }\end{array}$ & $\begin{array}{l}\text { Cation : DOWEX } \\
\text { Anion : DOWEX }\end{array}$ & - & [37] \\
\hline & 35 & 99.9 & $\begin{array}{l}\text { Cation : Fujifilm Type ॥ } \\
\text { Anion : Fujifilm Type ॥ }\end{array}$ & $\begin{array}{l}\text { Cation : Sulfonated } \\
\text { polystyrene } \\
\text { Anion : Quaternary } \\
\text { ammonium polystyrene }\end{array}$ & - & {$[42]$} \\
\hline \multirow{3}{*}{ MCDI } & 200 & 90.7 & $\begin{array}{l}\text { Cation : Sulfosuccinic acid } \\
\text { crosslinked polyvinylalcohol } \\
\text { Anion :- }\end{array}$ & - & $\begin{array}{l}\text { Activated } \\
\text { carbon }\end{array}$ & [43] \\
\hline & 200 & 96.4 & $\begin{array}{c}\text { Cation : Neosepta CMX } \\
\text { Anion :- }\end{array}$ & - & $\begin{array}{l}\text { Activated } \\
\text { carbon }\end{array}$ & [44] \\
\hline & 10 & 99.2 & $\begin{array}{l}\text { Cation : Neosepta CMX } \\
\text { Anion: Neosepta AMX }\end{array}$ & - & $\begin{array}{l}\text { Activated } \\
\text { carbon }\end{array}$ & {$[45]$} \\
\hline
\end{tabular}

현재 양산되고 있는 초순수 시스템 이온교환수지는 Styrene-DVB 겔 타입의 구조를 가지고 있으며, 양이온 교환 수지와 음이온 교환수지의 이온 교환 능력을 비슷하게 제조 하여 동시 세정 및 교환을 도모하고 있다. 일반 이온교환 수 지의 경우 단위 입자 크기가 $0.3 \mathrm{~mm} \sim 1.2 \mathrm{~mm}$ 로 불균일한 형태를 가지고 있지만, 일본 Mitsubishi사의 경우 입자 크기 가 $0.5 \mathrm{~mm} \sim 0.6 \mathrm{~mm}$ 로 균일하게 분포된 균일 입경 이온교 환수지 제작에 관한 노하우를 확보하고 있다.

\subsection{2. 전기 탈염 기술}

초순수 생산 공정에서는 혼상식 탈염(Mixed bed deionization, $\mathrm{MBDI}$ ) 공정이 역삼투 후처리 공정으로 사용된다. MBDI 방식 의 탈염기술은 무기이온의 제거에는 높은 효율을 보이나, 복 잡한 장치구성 및 운영 조작으로 인하여 현재는 전기탈염 (Electrodeionization, EDI) 공정으로 대체되었다. EDI 기술은 전기투석 장치와 이온교환 수지를 결합한 공정으로 전극 사이
의 공간을 이온교환수지로 채워서 운영하게 된다. RO-EDI 공정에서 발생한 처리수는 화학적 약품 투입 없이 12-18 $\mathrm{M} \Omega \cdot \mathrm{cm}$ 수준의 처리수 생산이 가능하다. ${ }^{37}$ 또한 기존 축전식 탈염(Capacitive deionization, CDI) 기술에서 역전위를 인가한 탈착시 이온의 재흡착으로 인해 사용이 제한되는 문제점를 해결하기 위해 분리막 축전식 탈염(Membrane capacitive deionization, $\mathrm{MCDI}$ ) 기술 개발이 활발히 진행되고 있다. $\mathrm{MCDI}$ 공정은 흡착시 염제거율이 기존 $\mathrm{CDI}$ 공정보다 약 $40 \%$ 높으며 ${ }^{38)}$, 탈착시 반대전극으로 탈착이온이 흡착되는 재흡착 을 방지하여 $\mathrm{CDI}$ 의 성능이 제고되는 장점을 가지고 있다. 초순 수 공정에서 사용되는 $\mathrm{EDI}$ 기술과 $\mathrm{MCDI}$ 기술에 관한 연구동 향을 Table 16과 같다.

\section{3. 유기물 산화용 자외선 발생 장비}

초순수 생산 시설에서 자외선을 이용한 유기물산화 공정 은 역삼투 공정 후단에 위치하여 역삼투 공정 처리수에서의 
Table 17. Feature of UV oxidizer for ultrapure water production by manufacturers.

\begin{tabular}{cccc} 
Manufacturers & Manufacturer A & Manufacturer P & Manufacturer E \\
Type & Horizontal, U-shape & Horizontal, U-shape & Horizontal, U / S / L-shape \\
\hline Lamp & - & $156 \mathrm{~W}$ & $155 / 170 \mathrm{~W}$ \\
\hline \multirow{2}{*}{ UV wavelength $(\mathrm{nm})$} & 185 (Oxidation) & 185 (Oxidation) & 185 (Oxidation) \\
\hline Safety switch & 254 (Sterilization) & 254 (Sterilization) & 254 (Sterilization) \\
\hline
\end{tabular}

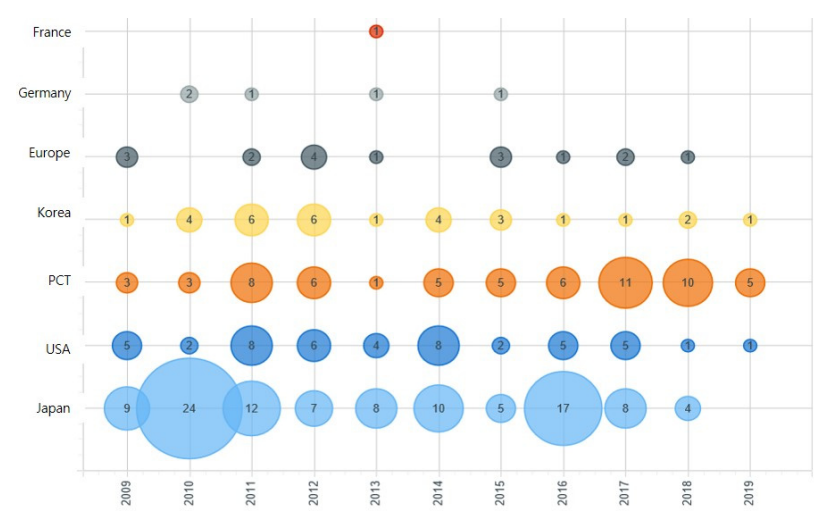

Fig. 10. Distribution of patent by countries related to ultrapure water treatment technology.

잔류 유기물질을 제거를 목적으로 한다. UV-C 영역의 185 $\mathrm{nm}$ 파장은 물분자를 분해하여 강력한 산화력을 갖는 수산 화라디컬을 생성시키며, 이 과정에서 생성된 수산화라디컬 이 산화제로써 잔류 유기물질을 제거하는 역할을 한다. 자 외선 반응기는 과거 수은 기반의 저압고출력(Low pressure high output, LPHO) 램프를 주로 사용하였으나, 최근에는 기존 수은 기반 저압고출력 램프를 개량한 아말감 LPHO 램프를 시스템에 적용하고 있다. 초순수 처리용 UV 시스템 주요 제조사 및 제품별 특징은 Table 17과 같다.

\section{5. 기술 특허 분석}

\section{1. 특허 조사 및 분석 방법}

국내외 기술 특허 분석은 Wisdomain 특허 데이터베이스 를 활용하여 진행하였으며, 한국, 일본, 미국, 유럽, PCT (Patent Cooperation Treaty, 특허협력조약) 특허를 대상으로 최근 10 년 이내에 출원 공개 또는 등록된 특허에 대하여 검 색 및 분석을 실시하였다. 초순수 기술 특허 조사에 사용된 검색식은 다음 Table 18 과 같다.

\section{2. 연도별 특허 출원 동향}

해당 검색식을 적용하여 검색된 최근 10 년 이내에 출원 공개 및 등록된 특허의 수는 Fig. 10과 같이 518건으로 집계 되었다. 이를 국가별로 분류하여 연도별 특허 건수를 나열 한 결과를 아래 그림에 나타내었다. 2010년 이후로 일본을

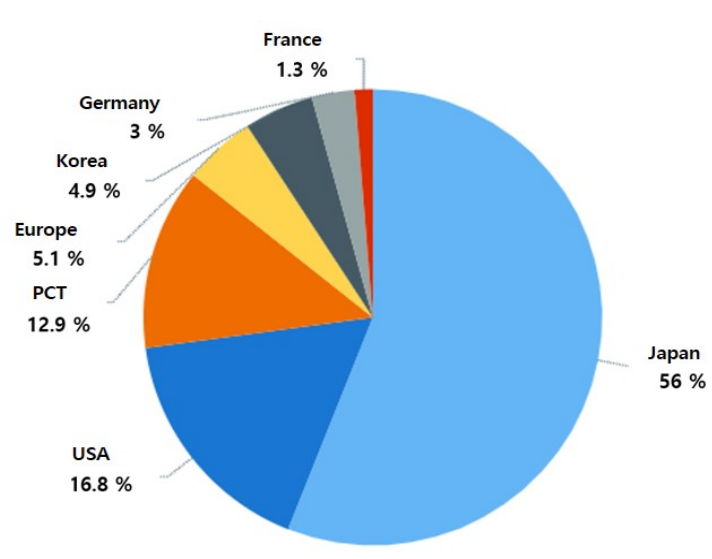

Fig. 11. Share of patent by countries related to ultrapure water treatment technology.

중심으로 관련 특허 출원이 급속히 증가하였으며, 현재까지 지속적인 기술 특허가 출원이 이루어지고 있다. 일본의 경 우 최근 10 년간 초순수 기술 관련 특허가 연평균 10 건으로 집계되었다.

\section{3. 국가별 특허 출원 동향}

초순수 장치 및 시스템 관련 특허는 Fig. 11과 같이 일본 이 전세계 특허 출원 중 $56 \%$ 를 차지하며 가장 큰 비율을 점유하고 있다. 뒤를 이어 미국 PCT 순으로 나타났으며 한 국은 $4.9 \%$ 를 점유하고 있다. 초순수 제조 장치 및 방법과 관 련된 기술이 일본에 의해 주도되고 있음을 확인할 수 있다.

\section{4. 특허 출원인 현황}

전세계 시장 초순수 특허 관련 출원인을 Fig. 12와 같이 분 석해 본 결과, 일본의 주요 초순수 관련 사업자인 Kurita사, Japan Organo사, Nomura사가 전체 출원 건수의 $71 \%$ 를 차지 하여 절대적인 기술 우위를 점하고 있음을 확인할 수 있다. Kurita사는 총 192 건의 특허를 출원하여 최다 출원인으로 확 인되었으며, 그 뒤를 이어 Oragano사 69건, Nomura Micro Science사 58건의 특허를 각각 출원하였다. 따라서 현재 초순 수 시장의 지배적 위치에 있는 일본의 3 개 기업이 초순수 관 련 연구 및 특허에서도 주도적인 위치를 점하고 있어 지속적 인 기술우위를 확보하려 노력하고 있음을 알 수 있다. 
Table 18. Search formula by country used for patent search.

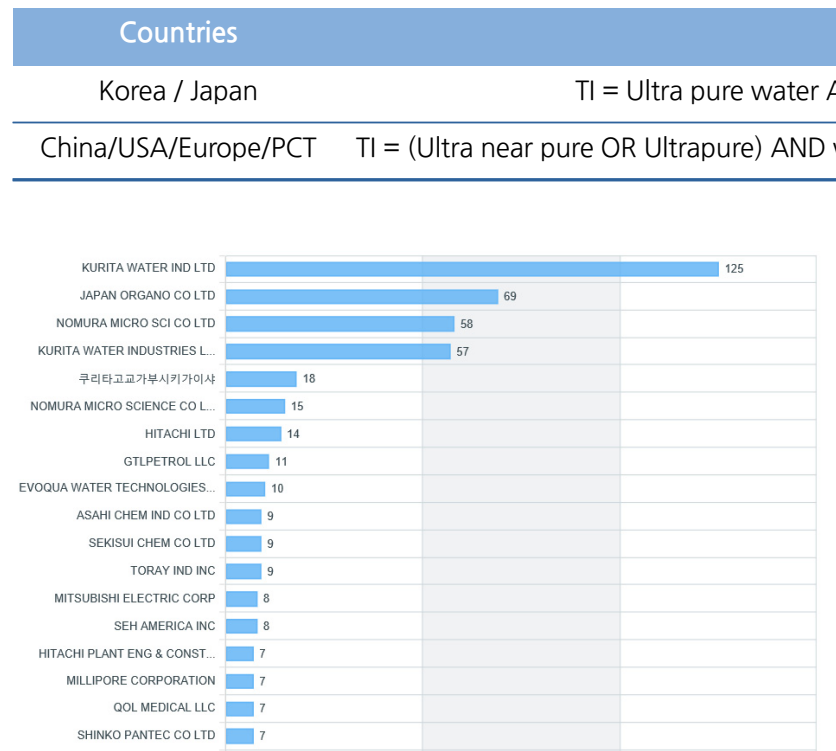

Fig. 12. Distribution of patent application by companies related to ultrapure water treatment technology.

\section{5. 단위 공정별 특허 출원 동향}

초순수 제조 기술별 지난 10 년간 국내외 특허 건수에 대 한 동향을 살펴보면 Fig.13과 같다. 이온 교환 기술관련 특 허가 226건으로 전체 초순수 공정 단위기술에서 $40 \%$ 로 가 장 높은 비율을 차지하고 있다. 뒤를 이어 자외선 장치, 역 삼투 분리막, 한외여과, 전기 탈이온 공정 순으로 특허 출원 이 됨을 알 수 있다.

\section{6. 주요 공정 기술 특허 현황}

초순수 제조와 관련한 기술은 각 회사별로 다양한 특허가 등록되어 있다. 초기에 등록된 특허는 주로 초순수 공정의 기본적인 조합에 대한 것이 다수이며, 최근 들어서는 특별 한 단위 공정 또는 장치를 추가하여 기존의 초순수 공정보 다 효율을 높이는 방법이 주로 특허로 등록되고 있다.

Kurita에서 등록한 US5,385,664 특허는 총 9개 공정을 거 쳐 초순수를 제조하는 방법을 제시하고 있으며, 이 방법은 $\mathrm{MF} / \mathrm{UF}$ (전처리), 1 차 역삼투, 2 차 역삼투, 혼합상 이온교환 수 지, 저압 UV 산화, 혼합상 이온교환수지, 그리고 최종 UF 공 정으로 구성되어 있다.46) Nomura에서 등록한 WO97/30939 특허는 막여과 전처리, 이온교환탑, 탈탄산탑, 역삼투, UV 산 화, 혼합상 이온교환탑, 진공 탈기장치, UV 산화, 혼합상 이온 교환탑, UF, 그리고 수질 모니터링 장치로 구성된 시스템을 제시하고 있다. ${ }^{47)}$ 한편, Organo의 특허 JP2004141805A에서 는 혼합상 이온교환수지에서 유출되는 입자로 인한 문제를 해결하기 위한 개선된 방식의 초순수 제조 조합공정을 제안 하고 있다. ${ }^{48)}$

Nomura의 특허 JP2013215679A는 안정적인 처리수의 수

\section{Search formula}

roduct OR system OR apparatus OR equipment) 
Table 19. Market-dominant materials, parts and equipment by ultrapure water production system unit technology.

\begin{tabular}{|c|c|c|c|c|}
\hline \multirow{2}{*}{\multicolumn{2}{|c|}{ Unit process }} & \multicolumn{2}{|c|}{ Major Manufacturers } & \multirow{2}{*}{ Domestic Manufacturer: } \\
\hline & & Japan & USA/Europe & \\
\hline \multirow{5}{*}{$\begin{array}{c}\text { Ultrapure water } \\
\text { process }\end{array}$} & RO membrane & Nitto Denko, Asahi Kasei, Toray & DOW & LG Chem. \\
\hline & UF membrane & Asahi Kasei & - & LOTTE Chem., SINOPECS \\
\hline & lon exchanger resin & Mitsubishi & DOW, Rohm\&Hass & SAMYANG \\
\hline & EDI & Kurita & DOW, EVOQUA & HUVIS WATER \\
\hline & UV oxidizer & Photo Science & Aquafine & ECOSET, FNS \\
\hline \multirow{2}{*}{ Other equipment } & Valve & Sekisui & - & ASUNG \\
\hline & Measuring instrument & Rion, PMS & GE, Sievers & - \\
\hline
\end{tabular}

로 인한 소재, 부품, 장비의 국산화율 제고가 주요 이슈로 대두되어 현재 국내에서 수처리 관련 기업들이 초순수 제조 용 핵심 소재 및 단위공정 및 실용화 연구 개발을 진행하고 있다. 그러나 외국 기업에 의해 설계/운영되고 있는 초순수 생산의 공정 특성상 단일 공정 내에서 외산 소재(특히 일본 산 소재)를 대체하여 국산 소재, 부품, 장비를 사용하는 것 은 거의 불가능한 실정이다. 따라서 초순수 생산 시스템의 국산화를 위해서는 국산 제품의 성능을 향상시키는 것과 더 불어, 국산 제품을 상용화할 수 있는 현장 적용 필요성이 대 두되고 있다.

\section{6. 결론}

\section{1. 요약}

과거 1980 년대 일본의 전자산업과 함께 발전되어온 반도 체용 공정에 사용되는 공업용수인 초순수는 반도체 사업의 성장과 기술발전에 따라 요구되는 물의 순도도 엄격해지고 있다. 이러한 초순수 생산을 위해 요구되는 수처리 단위공 정은 점점 더 복잡하고 다양해지고 있으며 최근 단위 공정 의 기술 발전은 수처리를 위한 약품을 절감하기 위해 전기 탈이온(EDI)과 같은 친환경 수처리공정을 개발하는 추세이 다. 아울러 반도체 제조공정의 용수 사용량을 절감하기 위 해 재이용시설을 운영하다 발생되는 난분해성 미량 물질 (i.e. Urea, THM, IPA 등)의 처리를 위한 신공정 개발에 관 한 연구를 진행 중이다.

초순수의 수질은 반도체 제품 생산의 불량률과 직결되므 로 수질과 수량의 안정성이 확보되는 공정 설계가 중요하며 단위 공정의 설계뿐만 아니라 단위 공정을 조합하여 배치하 는 시스템 설계가 초순수 기술의 핵심이며 전문업체별로 이 에 대한 기술력을 확보하고 있다. 특히, 전세계 초순수 관련 특허 동향 분석 결과 일본의 소수 기업에서 전세계 특허의 $71 \%$ 를 점유하고 있고, 이어서 미국과 한국이 특허 출원 순 위를 유지하고 있다. 따라서 초순수 수요가 많은 한국은 자 체 기술 개발이 필요하며, 초순수 생산을 위한 개별 단위 공 정에 대한 기술을 보유한 국내 기업들은 다양하게 있으나,
현장 적용이 가능한 상용화 기술 및 운영을 통한 성능 보장 능력이 부족하다. 따라서 초순수 분야의 국산화 기술 개발 은 단위 공정의 경우 현장 적용을 통한 상용화 기술 개발의 노력이 필요하며, 이렇게 개발된 국산 단위공정들의 조합 및 배치를 통해 수량과 수질 측면에서 신뢰성이 확보될 수 있는 초순수 생산 설계 기술에 대한 연구가 필요하다.

\section{2. 초순수 제조 핵심기술의 국산화를 위한 제언}

공장의 제품을 생산하는데 필요한 공업용수 중 반도체와 같은 첨단 산업의 제품 제조에 사용되는 고순도 공업용수를 “초순수”라고 현장에서 통칭하여 사용되고 있다. 이러한 초 순수 제조는 기존의 정수장에서 공급하는 공업용수(침전수) 에 대해 추가적으로 20 30여개의 단위 수처리 공정을 통해 물을 생산하는 기술 집약적이며 고도의 설계, 운영기술이 요구되는 엔지니어링 분야이다. 그동안 초순수 공정의 설계 및 적용되는 수처리 장비의 소재, 부품 등은 외국의 소수 업 체에 의해 기술력이 확보되고 현장에 적용되어 왔다.

전세계 반도체 및 전자 산업에 한국의 제조업체들의 비중 이 높은 만큼 국내 초순수의 사용량 및 요구되는 초순수 수 질 또한 세계적으로 한국의 산업 현장이 중요한 역할을 하 고 있음에도 불구하고 초순수 생산관련 핵심기술인 설계 및 장치는 외국의 기술에 의존하고 있어 이를 극복하기 위한 국산화 기술개발 노력이 필요하다.

이를 위해 초순수 생산을 위한 소재, 부품 그리고 장비의 국산화 개발뿐만 아니라 이를 이용한 장치 그리고 장치를 조합한 전체 시스템의 운영을 통해 설계 기술을 확보해야 하며, 초순수는 산업현장의 제품과 직결되는 공업용수이므 로 시스템의 성능평가를 통한 안정성을 고려할 필요가 있다. 마지막으로 엔지니어링 산업의 특성상 실규모 플랜트 구 축을 통한 성능 검증을 통해 실제 수요처로부터의 기술적 신뢰성을 입증하는 것이 중요할 것이다. 이러한 기술 개발 을 위해서는 다양한 수처리 장비가 집약되어 다양한 분야의 수처리 단위 공정의 요소 기술과 이를 집약하는 고도의 엔 지니어링이 요구되는 초순수 기술의 특성상 다양한 산, 학, 연 전문가들이 함께 기술을 개발할 필요가 있으며, 플랜트 
구성을 위한 비용 및 운영, 분석 비용이 고가이므로 정부차 원의 재정적 지원이 절실하다. 마지막으로 고순도의 초순수 는 수질 분석을 통해 기술 달성여부를 판단할 수 있지만, 직 접 제품생산에 사용하여 초순수 품질을 평가하는 것이 가장 중요하므로 연구개발 단계에서 구축한 초순수 플랜트를 대 상으로 제품 생산에 사용할 수 있는 수요처가 함께 기술 개 발에 참여한다면 특정 국가의 소수만이 보유하고 있는 초순 수 생산기술의 국산화 개발이 앞당겨 질것으로 예상된다.

\section{Acknowledgement}

본 연구는 K-water연구원 2020년 '맞춤형 고순도 공업용수 (ASTM D5127 E-1.3) 사업 추진을 위한 실증화 운영 기술 개발' 연구과제 및 산업통산자원부 ‘소재부품기술개발사업, 고순도(18 Mega ohms 이상) 초순수 생산을 위한 연속식탈 이온장치 개발(20010491)'으로 지원받은 과제입니다.

\section{References}

1. Law on Industrial Location and Development Home Page, http://www.law.go.kr/LSW//lsInfoP.do?lsiSeq=206412\&efYd =20190401\#0000, April(2019).

2. Water Law Home Page, http://www.law.go.kr/\%EB\%B2\%9 5\%ЕB\%A0\%B9/\%ЕC\%88\%98\%ЕB\%8F\%84\%ЕB\%B2\%95, Norvember(2019).

3. B. S. Choi, Issue report of ultrapure water industry and technology trends, 1st ed., Korea Agency for Infrastructure Technology Advancement(KAIA) Publishing, Anyang-si, Gyeonggi-do, Korea, pp. 1-16(2013).

4. Law on Industrial Integration and Factory Establishment Home Page, http://www.law.go.kr/LSW//lsInfoP.do?lsiSeq= 211677\&efYd=20191126\#0000, Norvember(2019).

5. K-water Water Quality Management Standards, K-water, 1st ed., K-water Publishing, Daedeok-gu, Daejeon, Korea, pp. 8-9(2019).

6. National Indicator System(Korea Customs Service) Home Page, http://www.index.go.kr/potal/main/EachDtlPageDetail. do?idx_cd=2455, June(2020).

7. M. Peter-Varbanets, W. Gujer, W. Pronk, Intermittent operation of ultra-low pressure ultrafiltration for decentralized drinking water treatment, Water Res., 46(10), 3272-3282(2012).

8. Water Supply and Water Quality Standards of Boiler Home Page, http://www.ks.or.kr/library/search/tosearch.do?kwd $=\% \mathrm{~EB} \% \mathrm{~B} 3 \% \mathrm{~B} 4 \% \mathrm{EC} \% 9 \mathrm{D} \% \mathrm{BC} \% \mathrm{~EB} \% 9 \mathrm{~F} \% \mathrm{AC}+\% \mathrm{EA} \% \mathrm{~B} 8 \%$ 89\%EC\%88\%98, Norvember(2017).

9. Master Plan for High Purity Industrial Water Plant Development for Gumi City Industrial Complex, 1st ed., Gumi City Publishing, Gumi-si, Gyeongsangbuk-do, Korea, pp. 41-43(2016).

10. American Society of Mechanical Engineer(ASME) Home Page, https://www.asme.org/publications-submissions/books/ find-book/asme-consensus-documents-feedwater-boiler-water- steam-lay-boiler-systems-cd-rom(2003).

11. American Society for Testing acd Materials International (ASTM) Home Page, https://www.astm.org/DATABASE. CART/HISTORICAL/D5127-13(2013).

12. K-water Daesan Customized Industrial Water Business Agreement, 1st ed., K-water Publishing, Daedeok-gu, Daejeon, Korea(2016).

13. S. Leea, S. R. Suwarno, B. W. H. Quek, L. Kim, B. Wu, T. H. Chong, A comparison of gravity-driven membrane (GDM) reactor and biofiltration + GDM reactor for seawater reverse osmosis desalination pretreatment. Water Res., 154, 72-83(2019).

14. K. H. Lee, Current Status and Strategy of Strategic Materials in Water Treatment, in Proceedings of 2019 Autumn Forum, 3(2), KSEE, BEXCO, Busan, pp. 14(2019).

15. Global Water Data Home Page, https://www.gwiwaterdata. $\operatorname{com}(2020)$.

16. The Chicago Sentinel Home Page, https://www.ccsentinel. com/uncategorized/ultrapure-water-market-latest-advancements -and-scope-2019-2025/(2019).

17. Media Analytics Lt, Market Insight: Global Water Market 2018, 2nd ed., Media Analytics Ltd Publishing, Oxford, UK, pp. 39-59(2017).

18. K-water, Industrial Water Market Analysis and Efficient Supply Plan, 1st ed., K-water Publishing, Daedeok-gu, Daejeon, Korea, pp. 79-101(2010).

19. K-water, The research of Based on Technology for Pure and Ultrapure water treatment plant, 1st ed., K-water Publishing, Daedeok-gu, Daejeon, Korea, pp. 50-62(2011).

20. Saramin Home Page, www.saramin.co.kr(2019).

21. Lenntech Home Page, https://www.lenntech.com/applications /semiconductor.htm(2020).

22. Nomura Home Page, https://www.nomura-nms.co.jp/english/ product/02_01_02.html(2020).

23. Ovivo Home Page, https://www.ovivowater.com/solution/ electronics/electronics/ultrapure-water-treatment-upw/(2020).

24. Dow Water Solution, Producing Ultrapure Water, 1st ed., Dow Water Solution Publishing, Wilmington, DE, U.S.A., pp. 2(2007).

25. H. Lee, Y. Jin, S. Hong, Recent transitions in ultrapure water (UPW) technology: Rising role of reverse osmosis (RO). Desalination, 399, 185-197(2016).

26. D. Mukhopadhyay, Method and apparatus for high efficiency reverse osmosis operation. United States Patent(US6537456B2), Mar(2003).

27. J. Wood, J. Gifford, J. Arba, M. Shaw, Production of ultrapure water by continuous electrodeionization, Desalination, 250(3), 973-976(2010).

28. J. Choi, J. Chung, Evaluation of urea removal by persulfate with UV irradiation in an ultrapure water production system. Water Res., 158, 411-416(2019).

29. J. Choi, J.-O. Kim, J. Chung, Removal of isopropyl alcohol and methanol in ultrapure water production system using a $185 \mathrm{~nm}$ ultraviolet and ion exchange system, Chemosphere, 156, 341-346(2016). 
30. B. Coulter, G. Sundstrom, S. D. Chris Hall, An advanced oxidation process update for removal of low organic levels, Ultrapure Water Micro, Phoenix, AZ, U.S.A., 1-22(2014).

31. J. Hutcheson, Ultrapure water: systems for microelectronics, Filtr. Sep., 43(5), 22-25(2006).

32. M. S. L. Tai, I. Chua, K. Li, W. J. Ng, W. K. Teo, Removal of dissolved oxygen in ultrapure water production using microporous membrane modules, J. Membr. Sci., 87(1-2), 99-105(1994).

33. D. Bhaumik, S. Majumdar, Q. Fan, K. K. Sirkar, Hollow fiber membrane degassing in ultrapure water and microbiocontamination, J. Membr. Sci., 235(1), 31-41(2004).

34. Kurita Home Page, Device for treating hydrogen peroxide water. https://www.kurita.co.jp/english/aboutus/press081112. html, November(2008).

35. P. Zhao, Y. Bai, B. Liu, H. Chang, Y. Cao, J. Fang, Process optimization for producing ultrapure water with high resistivity and low total organic carbon, Process Saf. Environ. Prot., 126, 232-241(2019).

36. I. Gorsky, Validating Purified Water Systems with a Lifecycle Approach, UltraPure Water Journal, November/December, pp. 1-15(2013).

37. J. Wang, S. Wang, M. Jin, A study of the electrodeionization process - high-purity water production with a RO/EDI system, Desalination, 132(1), 349-352(2000).

38. J. Choi, J. Choi, P. Dorji, H. K. Shon, S. Hong, Applications of capacitive deionization: Desalination, softening, selective removal, and energy efficiency, Desalination, 449, 118-130 (2019).

39. V. I. Fedorenko, Ultrapure water production by continuous electrodeionization method: technology and economy, Pharm. Chem. J., 38(1), 35-40(2004).

40. Ö. Arar, Ü. Yüksel, N. Kabay, M. Yüksel, Application of electrodeionization (EDI) for removal of boron and silica from reverse osmosis (RO) permeate of geothermal water, Desalination, 310, 25-33(2013).

41. J. H. Song, K. H. Yeon, J. Cho, S. H. Moon, Effects of the operating parameters on the reverse osmosis-electrodeionization performance in the production of high purity water, Korean J. Chem. Eng., 22(1), 108-114(2005).

42. V. Bhadja, B. S. Makwana, S. Maiti, S. Sharma, U. Chatterjee, Comparative efficacy study of different types of ion exchange membranes for production of ultrapure water via electrodeionization, Ind. Eng. Chem. Res., 54(44), 10974-10982(2015).

43. Y. J. Kim, J. H. Choi, Improvement of desalination efficiency in capacitive deionization using a carbon electrode coated with an ion-exchange polymer, Water Res., 44(3),
990-996(2010).

44. Y. J. Kim, J. H. Choi, Enhanced desalination efficiency in capacitive deionization with an ion-selective membrane, Sep. Purif. Technol., 71(1), 70-75(2010).

45. J. H. Lee, J. H. Choi, The production of ultrapure water by membrane capacitive deionization (MCDI) technology, J. Membr. Sci., 409-410, 251-256(2012).

46. M. Oinuma, T. Kawachi, Apparatus for producing ultrapure water, Kurita Water Industries Ltd, United States Patent(US5385664), Jan(1995).

47. M. Abe, S. Chino, Y. Nakamura, M. Kogure, Method and apparatus for producing ultrapure water, Nomura Micro Science Co Ltd, International patent(WO97/30939), Feb(1997).

48. K. Kawada, Method of producing ultrapure water, Japan Organo Co Ltd, Japanese patent(JP2004141805A), May(2004).

49. M. Iiyama, Y. Matsui, K. Kosaka, S. Awano, Ultrapure water production apparatus, Nomura Micro Science Co Ltd, Japanese patent(JP2013215679A), OCT(2013).

50. N. Arai, N. Ikuno, Water treatment method and ultrapure water producing method, Kurita Water Industries Ltd, United States Patent(US 2013/0048558 A1), Feb(2013).

51. B. L. Coulter, Method and system for providing ultrapure water, Evoqua Water Technologies LLC, United States Patent(US 8741155 B2), Jun(2014).

52. F. Ichihara, H. Sugawara, Ultrapure water production apparatus, Organo Corp, United States Patent(US2019/0217250), $\operatorname{Jun}(2019)$.

\section{Authors}

\section{Boungsu Kwon}

K-water Research Institute, Principal Researcher, ORCID(10 00000002-1994-8040

\section{Sangho Lee}

Department of Civil and Environmental Engineering, Kookmin University, Professor, ORCID (D) 0000-0002-1407-142X

\section{Seoktae Kang}

Department of Civil and Environmental Engineering, Korea Advanced Institute of Science and Technology, Professor, ORCID(i) 0000-0002-5113-3992

\section{Jaelim Lim}

K-water Research Institute, Ph.D., ORCID®0 0000-0002-3319-6754 